\title{
Reconstructions of deltaic environments from Holocene palynological records in the Volga delta, northern Caspian Sea
}

\author{
Keith Richards, ${ }^{1,2}$ Nataliya S Bolikhovskaya, ${ }^{3}$ Robert M \\ Hoogendoorn, ${ }^{4,5}$ Salomon B Kroonenberg, ${ }^{5}$ Suzanne AG Leroy ${ }^{6}$ and \\ John Athersuch ${ }^{7}$
}

\begin{abstract}
New palynological and ostracod data are presented from the Holocene Volga delta, obtained from short cores and surface samples collected in the Damchik region, near Astrakhan, Russian Federation in the northern Caspian Sea. Four phases of delta deposition are recognized and constrained by accelerated mass spectrometry (AMS) radiocarbon ages. Palynological records show that erosive channels, dunes (Baer hills) and inter-dune lakes were present during the period I I,500-8900 cal. BP at the time of the Mangyshlak Caspian lowstand. The period 8900-3770 cal. BP was characterized regionally by extensive steppe vegetation, with forest present at times with warmer, more humid climates, and with halophytic and xerophytic vegetation present at times of drought. The period 3770-2080 cal. BP was a time of active delta deposition, with forest or woodland close to the delta, indicating relatively warm and humid climates and variable Caspian Sea levels. From 2080 cal. BP to the present-day, aquatic pollen is frequent in highstand intervals and herbaceous pollen and fungal hyphae frequent in lowstand intervals. Soils and incised valley sediments are associated with the regional Derbent regression and may be time-equivalent with the 'Medieval Warm Period'. Fungal spores are an indicator of erosional or aeolian processes, whereas fungal hyphae are associated with soil formation. Freshwater algae, ostracods and dinocysts indicate mainly freshwater conditions during the Holocene with minor brackish influences. Dinocysts present include Spiniferites cruciformis, Caspidinium rugosum, Impagidinium caspienense and Pterocysta cruciformis, the latter a new record for the Caspian Sea. The Holocene Volga delta is a partial analogue for the much larger oil and gas bearing Mio-Pliocene palaeo-Volga delta.
\end{abstract}

\section{Keywords}

Caspian Sea, dinoflagellate cysts and ostracods, pollen and spores, sea level change, vegetation and climate, Volga delta

Received II March 20I4; revised manuscript accepted 30 May 2014

\section{Introduction}

The Volga delta, situated at the northern extreme of the Caspian Sea, is one of the largest deltas in the world and is a wetland region of global significance due to its high diversity of habitats for a large number of plant and animal species (Ramsar Sites Information Service, 2014), including many birds and fish. It is particularly important as a spawning ground for fish, including sturgeon, the principal source of caviar in the region. The delta also plays an important role in hydrological control for the lowlying lands of the north Caspian plain, which are 25-27 m below global sea level, and it is of strategic and economic importance due to its proximity to areas of oil and gas production. The sedimentary records within the delta are a 'natural laboratory' for sea level change (Kroonenberg et al., 2008), and studying those records will help in predicting future sea level trends. This is especially important as rises in water level of just a few metres have potential to cause serious damage to local livelihoods and infrastructure around the Caspian Sea coast. This study aims to examine the vegetation history of the delta from some of those sedimentary records and to reconstruct deltaic environments in the Holocene by means of palynological analysis, with additional information from ostracods. Changes in vegetation in the delta over time may be linked to a number of factors, such as changing climatic conditions, variations in fluvial discharge and the level of the Caspian Sea. This study may, therefore, help with understanding the recent vegetation and sedimentary history of the delta and perhaps contribute to managing future change in this fragile and unique locality.

The present-day Volga delta is an extreme example of a fluvially dominated delta and is unique in that it has formed in a closed basin, the Caspian Sea, unaffected by eustatic variations. The delta has moved frequently over distances of several hundreds of kilometres within the north Caspian plain in response to rapid Caspian Sea level changes during the Pleistocene and Holocene.

\footnotetext{
'KrA Stratigraphic Ltd, UK

${ }^{2}$ University of Amsterdam, The Netherlands

3 Moscow State University, Russia

${ }^{4}$ Deltares, The Netherlands

${ }^{5}$ Delft University of Technology, The Netherlands

${ }^{6}$ Brunel University, UK

${ }^{7}$ StrataData Ltd, UK
}

\section{Corresponding author:}

Keith Richards, KrA Stratigraphic Ltd, I 6 Albert Drive, Deganwy, Conwy, LL3I 9YY, UK.

Email: kr@paly.co.uk 
Those changes have occurred within an approximate range of $+50 \mathrm{~m}$ (above global sea level) in the early Khvalynian highstand (late Pleistocene) to $-80 \mathrm{~m}$ in the Mangyshlak early Holocene lowstand (Kroonenberg et al., 1997). Previous stratigraphic studies of the delta (e.g. Overeem et al., 2003) have shown the broad history of sedimentation during the Holocene, but without any significant age control and reliable means of correlation.

This article presents detailed palynological results and radiocarbon ages from the Damchik region of the lower delta (Figure 1a), and these are compared with those from other localities, principally Solenoe Zajmishche, near Chernyi Yar in the lower VolgaAkhtuba floodplain region approximately $250 \mathrm{~km}$ to the north (Bolikhovskaya, 1990; Bolikhovskaya and Kasimov, 2008, 2010). The Solenoe Zajmishche section ranges in age from $c$. 11,060 to $800 \mathrm{cal}$. BP. Intervals with frequent pollen from halophytic and xerophytic plants such as Amaranthaceae, Artemisia and Ephedra are interpreted as periods of mainly cold and arid climate, whereas intervals with common tree pollen, such as Quercus, Ulmus, Tilia and Carpinus, are indicative of warmer and more humid climates. These make up the 'QUTC' (the sum of Quercus, Ulmus, Tilia and Carpinus) group, originally described by Bolikhovskaya (1990), which is a useful marker assemblage for temperate forest biomes.

\section{The study area}

\section{Structural and geographical setting}

The Caspian Sea is the world's largest inland body of water containing over $40 \%$ of the lacustrine waters on the planet (Kaplin, 1995). The Caspian Sea receives freshwater input from a number of rivers of which the Volga, flowing into the north-western Caspian Sea, contributes by far the largest amount, over $80 \%$. Salinity of the surface waters is lowest (c. $3 \%$ or less) close to the Volga outflow, increasing to around $13.5 \%$ in the central and southern basins (Kosarev and Yablonskaya, 1994). The surface of the Caspian Sea is currently about $26.5 \mathrm{~m}$ below global sea level (Arpe et al., 2012; Naderi Beni et al., 2013a) and not connected directly to the world's oceans at the present time, although connections are known to have occurred in the recent geological past. A marine connection existed at the end of the Pliocene to beginning of the Pleistocene (Akchagylian stage) between c. 3.2 and 2 million years ago (Kosarev and Yablonskaya, 1994; Van Baak et al., 2013), and connections were re-established at various times throughout the Pleistocene (Badertscher et al., 2011; Forte and Cowgill, 2013; Rychagov, 1977; Tudryn et al., 2012). Most recently, high Caspian Sea levels, with connections to the Black Sea via the Manych Channel have occurred in the late Pleistocene (Khvalynian stage) as a result of increased runoff from glacial melt-waters after the 'Last Glacial Maximum' according to Chepalyga (2007), Svitoch (2010) and Yanina (2012).

The Caspian Sea, including the Volga delta region, is influenced by tectonics, regional topography and climate. During the Pliocene, the palaeo-Volga delta was situated about $500 \mathrm{~km}$ to the south of its present-day position (Kroonenberg et al., 2005; Reynolds et al., 1998) in response to the initial subsidence of the south Caspian basin and uplift of the Caucasus and Kopet Dag ranges (Allen et al., 2002). The middle Caspian basin (Derbent Depression) subsided at a later time (Dumont, 1998) and is separated from the south Caspian basin by the Apsheron Sill, an area of tectonic uplift (Allen et al., 2002, 2003) where present-day water depths vary between 80 and $200 \mathrm{~m}$ (Ferronsky et al., 1999; Kosarev and Yablonskaya, 1994). During the Pleistocene, at least within the last $700 \mathrm{kyr}$, extensive fluvio-deltaic sediments were deposited to the north of the present-day Caspian Sea coast, in response to major sea level changes, and these sediments formed the 'wandering Volga delta' (Kroonenberg et al., 1997). This Pleistocene delta complex exhibits much greater extremes of sedimentation than seen in the Holocene delta (Sidorchuk et al., 2009).

Many attempts have been made to reconstruct Holocene Caspian Sea levels (e.g. Chepalyga, 2007; Rychagov, 1997; Svitoch, 2009; Varushchenko et al., 1987). Most authors agree that there have been several transgressive/regressive cycles in the Caspian Sea during the Holocene, but there is no agreed model or consensus as to the precise timing and naming of the various Holocene Caspian Sea level events, due partly to a lack of uniformity in the dating methods and interpretations. The level of the Caspian Sea fell to about $80 \mathrm{~m}$ below its present level (Kroonenberg et al., 1997; Mayev, 1994; Rychagov et al., 2010) during the Mangyshlak stage at the beginning of the Holocene. The exposed shelfal areas were subject to aeolian processes, resulting in the formation of extensive east-west trending dune fields, the Baer hills. These underlie the Holocene delta (Kroonenberg et al., 2005; Overeem et al., 2003) and are visible to the west of the delta at the present time. They typically reach $20-25 \mathrm{~m}$ in height and often occur in association with shallow freshwater to saline lakes (Losev et al., 1998). Subsequently, it is generally agreed that Caspian Sea levels were variable, but mostly high, in the early to mid-Holocene with maximum levels of around -24 to $-20 \mathrm{~m}$ below present-day global sea level (c. 3-7 $\mathrm{m}$ above present-day levels) between c. 9000 and c. 5000 years ago (Chepalyga, 2007; Rychagov, 1997). Further highstands then occurred, with Caspian Sea levels reaching -25 to $-19 \mathrm{~m}$ below present-day global sea level (Naderi Beni et al., 2013a, 2013b) within the last few hundred years, following a late Holocene lowstand event known regionally as the Derbent. Overeem et al. (2003) showed how the very recent sediments and vegetation in the Damchik region have evolved over a period of (mainly) sea level fall since 1935, based on aerial photographs and vegetation maps. Between 1935 and 1977, Caspian Sea levels fell by c. $3 \mathrm{~m}$, from $c$. -26 to $c$. $-29 \mathrm{~m}$ (Kosarev and Yablonskaya, 1994) leading to an outbuilding of the delta by about $10 \mathrm{~km}$ (Alekseevskiy et al., 2010). Deposition was then fairly stable during a period of Caspian Sea level rise of around $2.7 \mathrm{~m}$ between 1978 and 1995; a minor fall has since been recorded and present-day levels fluctuate at around - $26.5 \mathrm{~m}$ (Arpe et al., 2012; Naderi Beni et al., 2013a).

\section{Hydrography and climate}

The Volga catchment drains an area of approximately 1.38 million $\mathrm{km}^{2}$, with a total length of the main stream of $3700 \mathrm{~km}$ (Sidorchuk et al., 2009). Much of the catchment falls within the temperate continental climate zone (Kosarev, 2005), but extends into humid mid-latitudes (Leroy et al., 2007). The catchment as a whole extends from approximately $46^{\circ} \mathrm{N}$ to $62^{\circ} \mathrm{N}$ and from $32^{\circ} \mathrm{E}$ to $60^{\circ} \mathrm{E}$, and thus drains an area with considerable diversity in climate and topography. In the Volga catchment area, mean annual temperature ranges from $3^{\circ} \mathrm{C}$ in the north to $9^{\circ} \mathrm{C}$ in the south, with mean annual precipitation ranging from $750 \mathrm{~mm}$ in the north to $150 \mathrm{~mm}$ in the south (Sidorchuk et al., 2009; Figure 1b). In the delta region, average monthly temperatures vary from $26^{\circ} \mathrm{C}$ in July to $-8^{\circ} \mathrm{C}$ in January (Knystautas, 1987), occasionally reaching as high as $c .45^{\circ} \mathrm{C}$ in summer and as low as $c .-40^{\circ} \mathrm{C}$ in winter, with rainfall fairly evenly distributed through the year at between 200 and $250 \mathrm{~mm}$ (Losev et al., 1998). Much of the shallow north Caspian area freezes in winter with an average of 120 140 days of ice cover and typical ice thicknesses of $20-30 \mathrm{~cm}$ in the Volga mouth region (Kosarev, 2005); ice-gouge features several kilometres in length and up to $200 \mathrm{~m}$ wide occur on the sea bed in the northern Caspian Sea (Ogorodov and Arkhipov, 2010). Discharge from the Volga between 1880 and 1980 averaged $241 \mathrm{~km}^{3} / \mathrm{yr}$, with approximately $60 \%$ of the total discharge occurring during the snow melt and floodwater period of April to June (Kosarev and Yablonskaya, 1994), although significant variations 

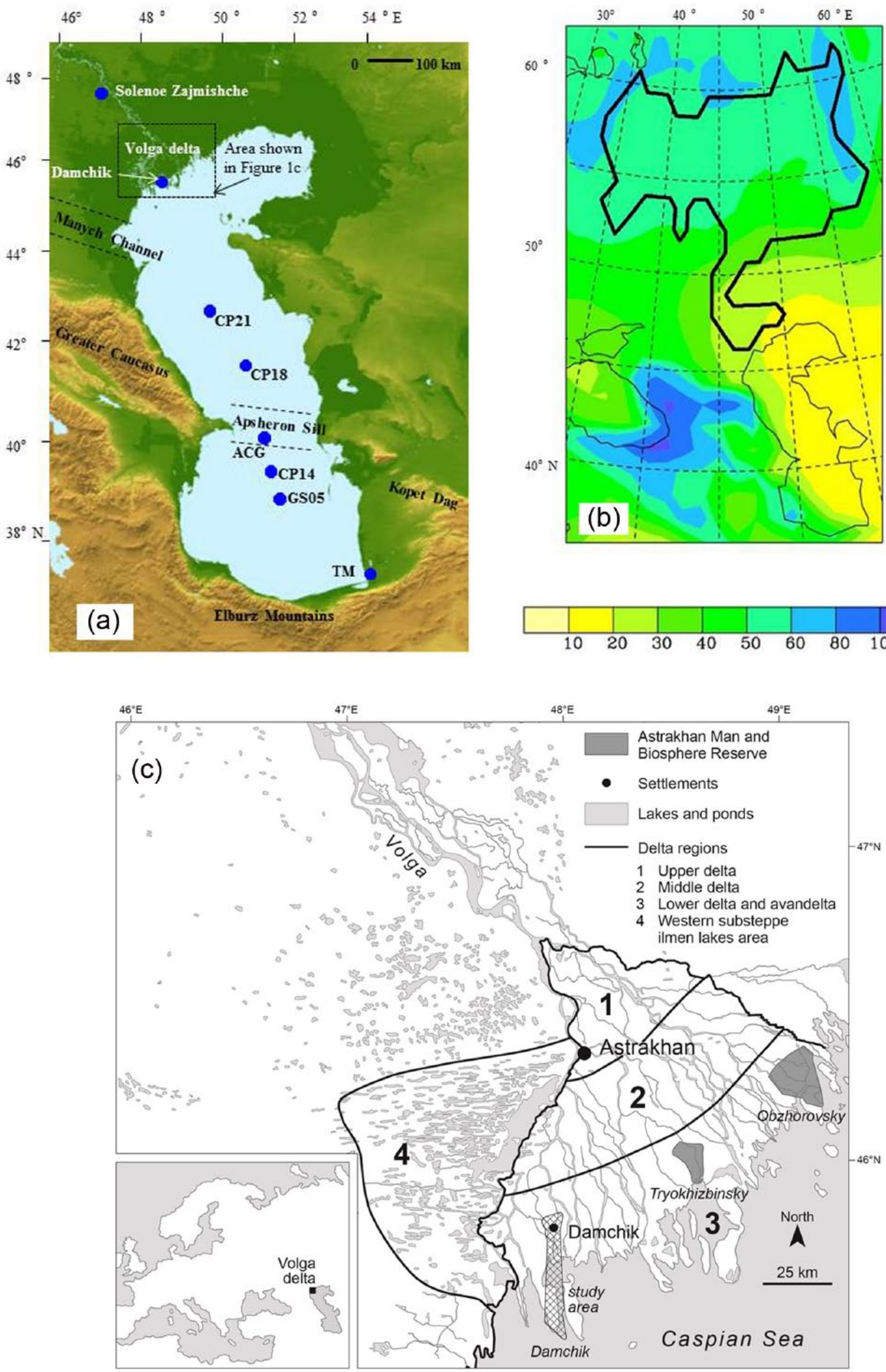

Figure I. (a) Caspian Sea and Volga delta location map showing main geographical features and study sites referred to in the text (ACG = Azeri-Chirag-Gunashli oilfield), (b) mean annual precipitation for the Volga drainage basin (shown with black outline) and Caspian Sea region; colours indicate millimetres per month values (data from K Arpe based on ECMWF interim reanalysis) and (c) location map showing the present-day position of the Volga delta and the study area (Damchik) within the Astrakhan Man and Biosphere Reserve. The main delta regions (after Losev et al., 1998; Rusakov, 1990) are shown. (For interpretation of the colours in this figure, the reader is referred to the online version of this article.)

from this average do occur (Kroonenberg et al., 1997; Sal'nikov et al., 2010). Evaporation is most pronounced in the summer and may reach $175-200 \mathrm{~mm} / \mathrm{month}$ within the delta (Losev et al., 1998) and has a major influence on Caspian Sea level (Arpe et al.,
2012). Winds in the northern part of the Caspian Sea are predominantly from the east, and less frequently from the west and northwest (Kosarev, 2005). Strong winds are relatively infrequent, but storm surges do occur, especially in the shallow waters in the 


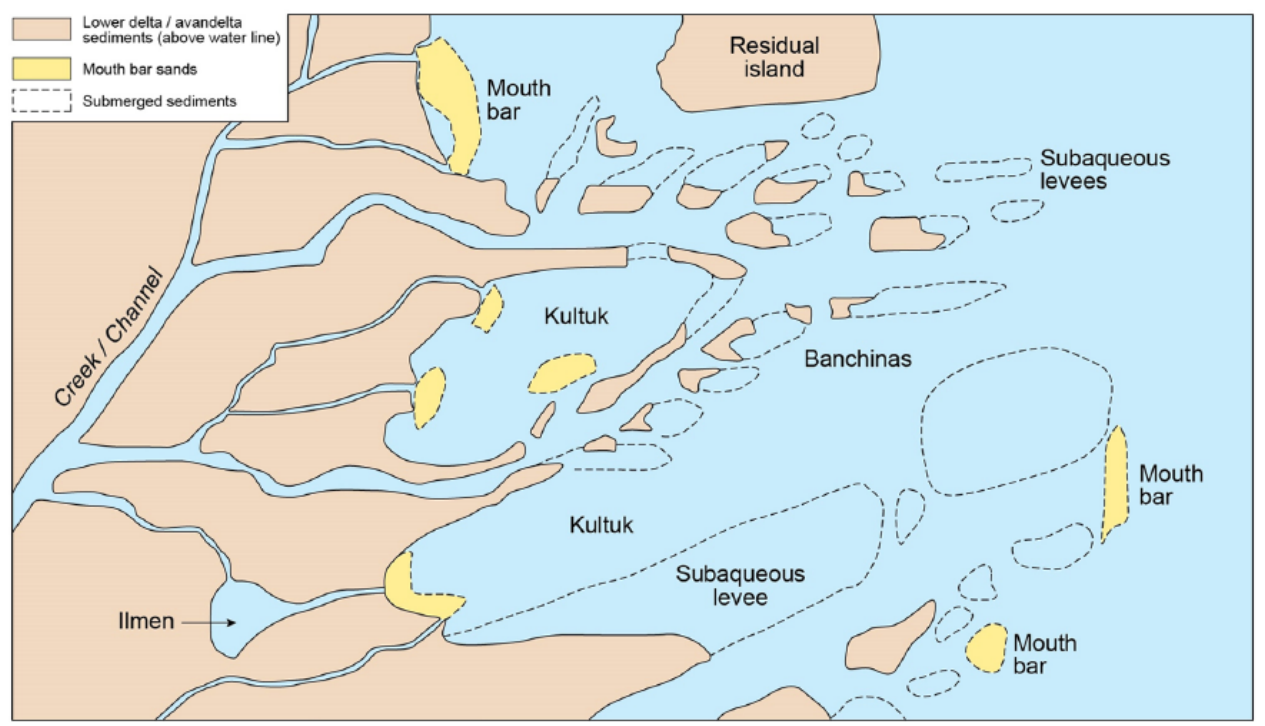

Figure 2. Schematic summary of depositional features in the present-day Volga delta (after Belevich, 1956, 1963). Approximate location is shown in Figure 4a.

north Caspian Sea region (Ivkina, 2010) and periodically in the delta region, with wave heights up to $1.5 \mathrm{~m}$, reaching up to $3-4 \mathrm{~m}$ in extreme cases (Kosarev, 2005). For example, storm surges of 2-3 $\mathrm{m}$ above normal occurred in 1952 and caused flooding as far north as the city of Astrakhan (Kroonenberg et al., 1997). True tides are absent in the Caspian Sea (Naderi Beni et al., 2013a), although 'seiches' do occur (Kosarev and Yablonskaya, 1994) resulting in minor 'tidal' ranges of $10 \mathrm{~cm}$ or less in the coastal regions (Spidchenko, 1973).

\section{Volga delta sedimentation}

The present-day Volga delta is a gently sloping ramp delta with a slope gradient of around $5 \mathrm{~cm}$ per $\mathrm{km}$. Sediment load carried by the river consists mostly of fine sand, silt and clay. The delta bifurcates regularly because of the low gradient and fine grain size, resulting in more than 800 outlets into the Caspian Sea along a coastline of c. $200 \mathrm{~km}$ (Kroonenberg et al., 1997, 2005; Overeem et al., 2003; Figure 1c). The sedimentary history and ongoing sedimentary processes in the Volga delta are largely controlled by changes in the water level of the Caspian Sea, which, in turn, are driven by catchment climate and river outflow. The apex of the present delta is situated close to the city of Astrakhan and the Akhtuba tributary at an altitude of $-22 \mathrm{~m}$, with upper delta plain $(-22$ to $-25 \mathrm{~m})$ and lower delta plain (below $-25 \mathrm{~m})$ sediments deposited to the south (Rusakov, 1990). The upper delta plain region contains remnants of the Baer hills, and topographic lows between these hills are flooded by the Volga during peak discharge (Kroonenberg et al., 1997). The lower delta plain consists mainly of alluvial sediments deposited since the Caspian Sea lowering in the 1930s and contains the main Volga channels that were incised during the Derbent lowstand within the last 1000 or so years, with active progradation now occurring close to the delta front. Further seaward is an extensive submerged pro-delta (avandelta) region which extends some $80 \mathrm{~km}$ offshore in water depths of no more than about $4 \mathrm{~m}$, and is formed mostly of eroded and re-deposited sediments (Kroonenberg et al., 1997).

The main sedimentary features and processes are described by Belevich (1956, 1960, 1963; Figure 2). During periods of sea level fall, the delta builds out (progradation) and mouth bars are formed at the delta front during times of peak river flooding. These mouth bars obstruct the water flow, becoming sub-aqueous levees, which then extend seawards. The inter-distributary bays (kultuk) are freshwater bodies (Belevich, 1956), with water depths usually of less than $1.5 \mathrm{~m}$, containing freshwater and mostly floating vegetation (Kroonenberg et al., 1997). These kultuk are frequently connected to the avandelta region but may become isolated from open water during rapid progradation, and form delta lakes (ilmen). During periods of sea-level rise, deposition occurs in the more landward parts of the delta (aggradation) and the ilmen often become silted up. This pattern of sedimentation is likely to have occurred throughout the Holocene, at least subsequent to the early Holocene Mangyshlak regression (Kroonenberg et al., 2005), with alternating progradation and aggradation leading to a lateral shift in sedimentation and channel migration.

\section{Vegetation}

The Volga catchment encompasses a large variety of vegetation types, which influence the pollen types that are dispersed into the delta and Caspian Sea. The upper reaches of the Volga extend into mixed and broad-leaved forests of central and eastern areas of the East-European Plain where species of Quercus, Tilia, Ulmus, Acer, Fraxinus, Alnus, Betula and Pinus dominate now, and up to the southern limits of boreal coniferous (taiga) forest where Picea abies, P. obovata, Abies sibirica, Pinus sylvestris, Larix sukaczewii, Betula pubescens and B. pendula are common components (Figure 3). The river then flows southwards through steppe and semi-desert vegetation, characterized by Poaceae, Asteraceae, Artemisia and Amaranthaceae ${ }^{1}$ (Knystautas, 1987).

The Volga delta lies within the Volga-Akhtuba semi-arid province, which supports semi-desert vegetation, with frequent Artemisia and Poaceae. Limited forest vegetation dominated by Salix, Populus, Acer, Quercus, Fraxinus, Ulmus, Betula and Alnus grows in the floodplain areas (Bolikhovskaya and Kasimov, 2008; Nikolayev, 2007). The upper delta region, approximately to the north and north-east of Astrakhan, is now largely used for agriculture and grazing, with the natural vegetation consisting of dry steppe and semi-desert. The middle delta region occurs in a south-west to north-east belt approximately $25 \mathrm{~km}$ wide from north to south, and is located to the south and east of Astrakhan (Figure 1c). Part of this region is also used for agriculture and grazing, although large areas are flooded by the Volga for several months of the year, and are colonized by grassland and reedbeds. The natural (and some artificial) levees between the river channels are colonized by willows, mainly Salix alba and S. triandra (Losev et al., 1998) with other trees, including Fraxinus and Ulmus (Bolikhovskaya and Kasimov, 


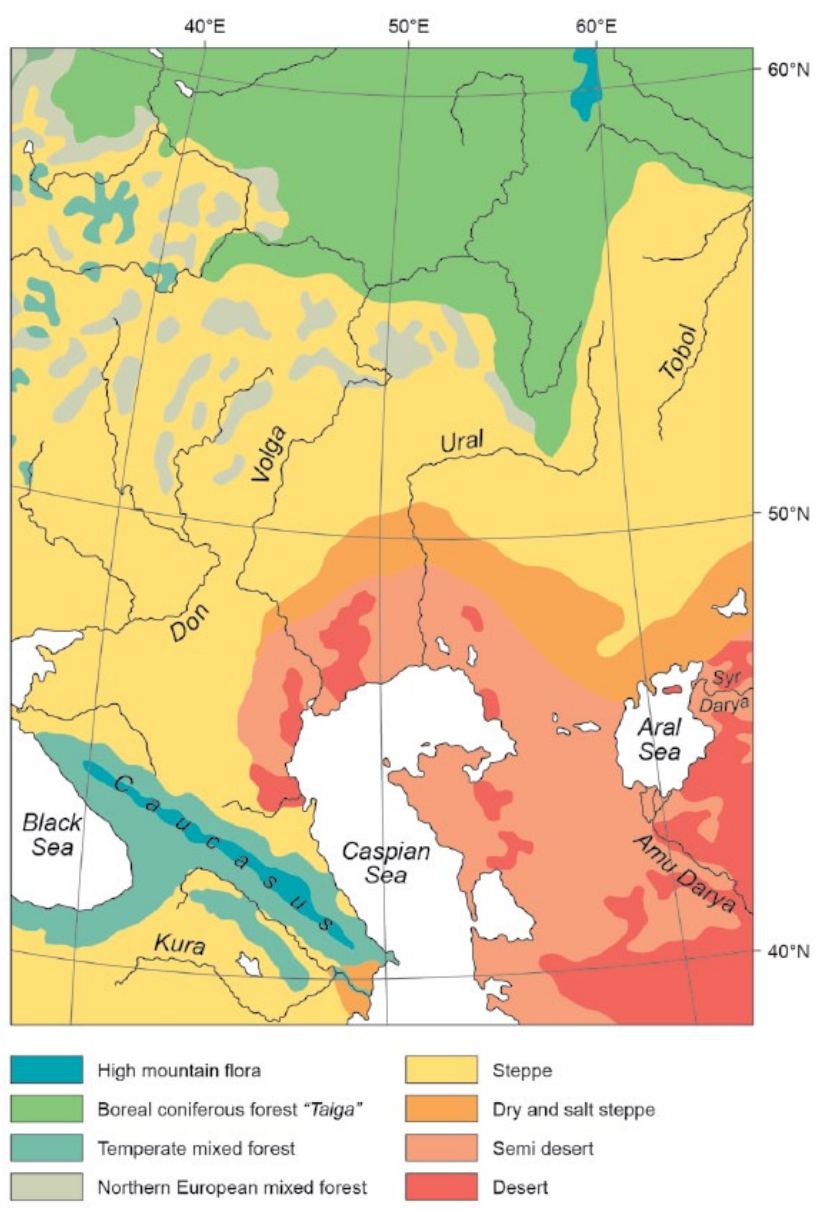

Figure 3. Simplified vegetation map for the northern Caspian region, including the Volga catchment area (from various sources).

2008, 2010). When the Volga is confined to its river channels, the middle delta region is generally dry, and areas in between the river branches may support halophytic or xerophytic vegetation, including Amaranthaceae (e.g. Suaeda and Salicornia), Ephedraceae (Ephedra distachya) and Tamarix. The Baer hills region to the west supports mainly desert vegetation with Artemisia, Halocnemum, Suaeda and Calligonum leucocladum (Bolikhovskaya and Kasimov, 2010; Losev et al., 1998).

The most studied locality within the lower delta and avandelta is the Damchik region of the Astrakhan Man and Biosphere Reserve (Lychagin et al., 1995), where the cores for this present study were collected. This area contains both permanent and weakly running rivers and streams (Figure 4a) as well as permanent lakes (ilmen), seasonally dry lakes and freshwater embayments $(k u l t u k)$. The main river channels are bounded by natural levees that are typically $0.5-2 \mathrm{~m}$ above low water level (Labutina et al., 1995; Figure 4b). The flora and vegetation of the Damchik region have been described in detail by Baldina et al. (1999) and mapped by Labutina et al. (1995). In the northern region, vegetation consists of forests, shrublands and grasslands. The forests include willow forest (dominated by $S$. alba and $S$. triandra) and mixed forest that includes species of Salix as well as Populus (native) and Fraxinus (introduced). Shrublands are limited to stands of Tamarix (on saline soils) and Rubus and Carex (on levees). Short grasslands occur at slightly higher elevations, which are less inundated by floodwater and contain halophytic species such as Aeluropus, Suaeda and Salicornia. Tall grasslands include mainly reedbeds, dominated by Phragmites and Typha in the partially flooded areas. In the permanently flooded regions, Labutina et al. (1995) classified the vegetation into three main types: emergent, floating and submerged. The emergents include mainly Phragmites, Typha, Sparganium, Nelumbo and Salvinia; the floating vegetation is characterized by Trapa, Nymphoides, Nymphaea and Nuphar, with submerged associations dominated by Potamogeton, Ceratophyllum, Butomus and Vallisneria spiralis (Hydrocharitaceae). A notable feature is the presence of Nelumbo nucifera ('lotus'), a species mostly found in tropical latitudes (Baldina et al., 1999); it is unclear if this species is native to the Volga delta, but it does occur frequently, forming dense stands in the avandelta region (Baldina and Labutina, 2010). A simplified map of the vegetation in the Damchik region is shown in Figure 4c, re-drawn from the original maps of Labutina et al. (1995) and Overeem et al. (2003).

\section{Caspian dinocysts}

Dinoflagellate cysts (dinocysts) are an important palynological component in Pleistocene and Holocene sediments of the Caspian Sea region. Dinocysts occurring include forms originally described from the Black Sea such as Spiniferites cruciformis and Pyxidinopsis psilata (Wall and Dale, 1973; Wall et al., 1973), as well as Impagidinium caspienense and Caspidinium rugosum described from the Caspian Sea (Marret et al., 2004). The requirements and salinity tolerances of all these taxa are not entirely known but, in general, they are all characteristic of low salinity waters such as those present in the Caspian Sea at the present time. S. cruciformis is also known to occur in freshwater settings (Kouli et al., 2001; Leroy and Albay, 2010). All these dinocyst species can exhibit very varied morphologies (e.g. Leroy, 2010; Marret et al., 2004; Mudie et al., 2001), the exact significances of which are not yet fully understood but are most probably related to water temperature and salinity (Zonneveld et al., 2013). The euryhaline species Lingulodinium machaerophorum and the cosmopolitan genus Brigantedinium also occur. Process length in $L$. machaerophorum varies (Lewis and Hallett, 1997; Mertens et al., 2009), with mainly short-processed forms $(<6 \mu \mathrm{m})$ occurring in the Caspian Sea at the present time (Mertens et al., 2012), thought to be a response to the relatively low salinity. Leroy et al. (2013b) suggested that L. machaerophorum abundances may have increased since $c .3200 \mathrm{cal}$. BP, possibly in response to rising sea surface temperatures.

Several dinocyst records are available from the offshore Caspian area (Leroy et al., 2007). Cores CP-18 and CP-21 (Figure 1a) are dominated throughout by $I$. caspienense, with slightly increased amounts of S. cruciformis and L. machaerophorum in the lower to mid-sections, whereas high numbers of $P$. psilata and $S$. cruciformis are present prior to $c$. 4000 cal. BP in core CP-14. Core TM (Leroy et al., 2013a) from the south-eastern coastal region also has abundant $I$. caspienense in the lower section of the core $(10,640-7500 \mathrm{cal}$. BP) and varied frequencies of $S$. cruciformis, I. caspienense and L. machaerophorum in the mid to late Holocene intervals. In core GS05 in the offshore area, part of the early Holocene (equivalent to the Mangyshlak local stage) has an assemblage dominated by I. caspienense (Leroy et al., 2013c).

\section{Methods and materials}

\section{Cores and sampling}

A detailed geophysical survey of the study area in the lower Volga delta was carried out in 2006, consisting of shallow seismic surveys along the main river channels (Figure 4d) in the Damchik region (Kroonenberg et al., 2008). Over $70 \mathrm{~km}$ of shallow seismic data were collected, focused on the uppermost $10 \mathrm{~m}$ of sediment, and the principal seismic facies types used to characterize sedimentation and stacking patterns (Hoogendoorn et al., 2010). A total of 25 shallow cores were collected, also in 2006, with core localities chosen based on the results of the seismic survey, to give representative coverage of all localities and sediment types 

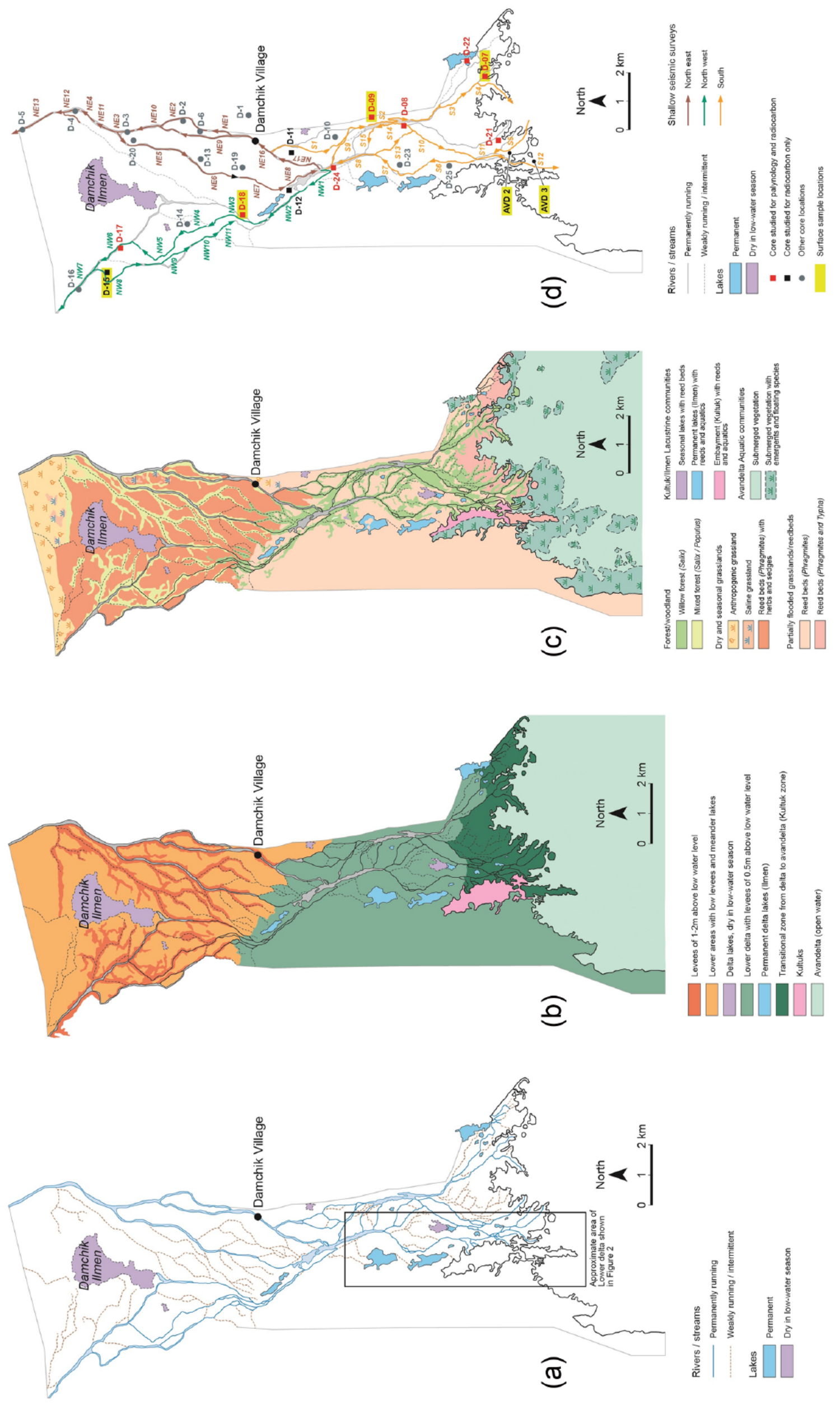
from all accessible parts of the study area. Cores of up to $c .10 \mathrm{~m}$ in length (average $8.7 \mathrm{~m}$ ) were taken using a piston corer and labelled as D-01 to D-25. Eight cores were chosen for detailed palynological analysis, giving a spread of localities from the proximal (northern) and distal (southern) parts of the study area, with additional spot samples examined for calcareous microfossils. Surface samples for modern pollen and calcareous microfossils, principally ostracods, were also collected from six localities (Figure 4d).

\section{Radiocarbon dating}

In all, 44 samples were selected for accelerated mass spectrometry (AMS) radiocarbon dating, with conventional ${ }^{14} \mathrm{C}$ ages converted into calibrated years BP by Beta Analytic Ltd. using the IntCal09 database (Reimer et al., 2009). The dated material consisted of presumed in situ mollusc shells, and in a few cases ostracod shells and plant or woody material. For the purposes of this present study, no adjustment for reservoir or 'hardwater' effects has been made (i.e. $\Delta R=0$ ). The lower Volga delta regions, where the dated samples were obtained, are largely freshwater regions. This is substantiated by 42 out of the 44 samples studied having $\delta^{13} \mathrm{C}$ values of $-5 \%$ or less. Radiocarbon ages shown in the text are in calibrated years BP (cal. BP), and the individual ages shown are the 'intercept' points with the IntCal09 curve (rounded to the nearest 10 years unless otherwise indicated).

\section{Palynomorphs and calcareous microfossils}

In total, 231 samples were analysed palynologically from cores D-07, D-08, D-09, D-17, D-18, D-21, D-22 and D-24, with samples being selected as representative of the lithological units present in each core. The sample coverage averages out at between two and three samples per metre, and is sufficient to give a good representation of the main sedimentary units. All core and surface samples were processed using cold $\mathrm{HCl}(20 \%)$ and cold $\mathrm{HF}$ $(40 \%)$, followed by a second $\mathrm{HCl}$ treatment. Residues were then sieved through $10 \mu \mathrm{m}$ mesh and finally mixed with $1 \%$ poly vinyl alcohol before mounting in Norland Optical Adhesive No 63 . Counts of all palynomorphs were made, with the aim of obtaining a minimum of 200 pollen grains, excluding unknowns, aquatics and reworked taxa, which make up the pollen sum (PS). Additional quantitative counts were made of non-pollen palynomorphs (NPP), including fern spores, fungal bodies, algae, dinocysts and reworked forms. Most of the pollen types could be identified with reference to sources, including Erdtman (1971) and Moore and Webb (1978). The Russian pollen and spore floras of Kuprianova and Alyoshina $(1972,1978)$ and Bobrov et al. (1983) were also used. In situ dinocysts were identified with reference to Marret et al. (2004), Mudie et al. (2001), Popescu et al. (2009), Sorrel et al. (2006) and others.

CONISS cluster analysis (Grimm, 1987) was applied to identify pollen and non-pollen zones. Two separate CONISS analyses were made for each section. The first includes only the PS and the clusters obtained are labelled P1-P4 $(\mathrm{P}=$ Pollen). The second CONISS analyses were run using a separate percentage sum of the totals of the other groups (aquatics, algae etc.). These clusters are labelled $\mathrm{N} 1-\mathrm{N} 4(\mathrm{~N}=$ Non-Pollen). Assigned clusters are prefixed with the number of the core (e.g. 7-P1, 7-P2, 8-N2, 8-N3, etc.). Where counts are less than 50 , individual occurrences are not shown on percentage diagrams and are excluded from the CONISS analysis.

Samples studied for ostracods and other calcareous microfossils were washed through a $125 \mu \mathrm{m}$ sieve and the residue dried at $100^{\circ} \mathrm{C}$. Individual specimens were picked from the residue and identifications made principally with the aid of Agalarova et al. (1961) and Meisch (2000).
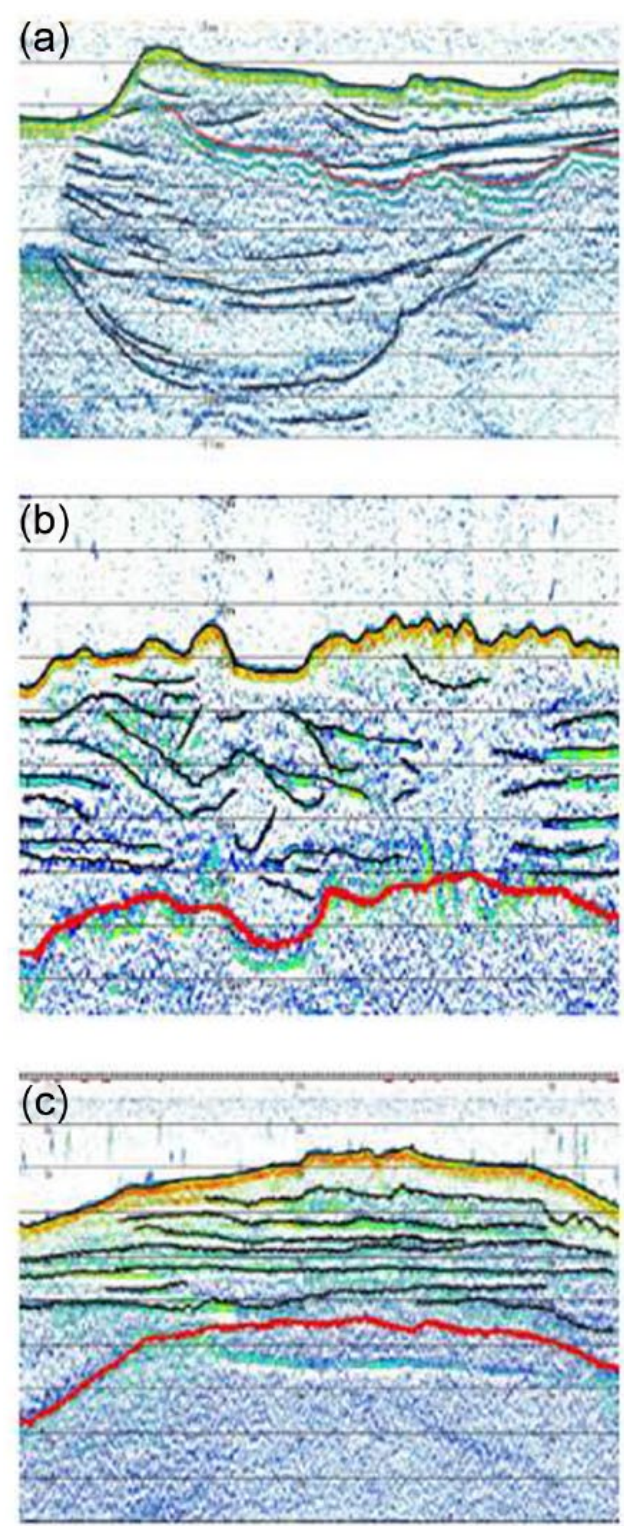

Figure 5. Examples of shallow seismic profiles. (a) channel sets, (b) heterogeneous sets and (c) parallel sets (after Hoogendoorn et al., 2010).

\section{Results}

\section{Seismic, lithology and radiocarbon dating}

Of the principal seismic facies, distinct channel features (Figure 5a) are visible throughout the delta, notable in the region of the D-08, D-09 and D-24 core localities (survey S9). Heterogeneous sets (Figure $5 \mathrm{~b}$ ) are also widespread and include individual beds of between $10 \mathrm{~cm}$ and $1 \mathrm{~m}$ thick, interpreted as small-scale channel/levee complexes, highstand delta front deposits and possibly terminal splays occurring, for example, close to the D-22 core locality (survey S3). More evenly bedded parallel sets (Figure 5c) mostly coincide with grey clays and are associated with highstand sedimentation, mainly in the lower delta and avandelta region, for example, at the D-07 core locality (survey S4). There are no direct tie points between the cores and the seismic lines, as the cores were taken on land and the seismic data are from the adjacent fluvial channels. Typical lithofacies include laminated dark grey clays, silty clays and fine sands, which most probably represent mainly avandelta and kultuk sediments, brown massive finegrained sands indicative of fluvial channels and reddish brown silty clays and fine sands, which occur in the deeper parts of several boreholes and represent the sub-strata of the Holocene delta 
Table I. Accelerated mass spectrometry (AMS) radiocarbon dates from the Damchik cores in conventional ${ }^{14} \mathrm{C}$ years and in calibrated years before present (cal. BP) using the IntCal09 calibration curve. Calibrated ages are not corrected for reservoir effect. $U=U$ trecht, B = Beta Analytic Inc. The $95 \%$ probability $2 \sigma$ ranges are shown as well as the best-fit 'intercept' with the IntCal09 curve as calculated by Beta Analytic Inc. (rounded to the nearest 10 years).

\begin{tabular}{|c|c|c|c|c|c|c|c|c|c|}
\hline \multirow{3}{*}{$\begin{array}{l}\text { Lab. no. } \\
\text { B-372497 }\end{array}$} & \multirow{3}{*}{$\begin{array}{l}\text { Core } \\
\text { D-07 }\end{array}$} & \multirow{3}{*}{$\begin{array}{l}\text { Depth }(\mathrm{m}) \\
7.00-20\end{array}$} & \multirow{3}{*}{$\begin{array}{l}\text { Material } \\
\text { Shells }\end{array}$} & \multirow{3}{*}{$\begin{array}{l}\delta^{13} \mathrm{C} \\
-3.6\end{array}$} & \multirow{2}{*}{\multicolumn{2}{|c|}{$\frac{\text { Conventional age }}{{ }^{14} \mathrm{C} \text { yr BP }}$}} & \multirow{2}{*}{\multicolumn{2}{|c|}{$\frac{\text { Calibrated ages (IntCal09) }}{2 \sigma \text { range }(95 \%)}$}} & \multirow{3}{*}{$\begin{array}{c}\text { Intercept age } \\
7820\end{array}$} \\
\hline & & & & & & & & & \\
\hline & & & & & 7350 & \pm 40 & 7720 & 7910 & \\
\hline B-372498 & D-07 & $7.30-40$ & Shells & -1 & 7270 & \pm 40 & 7650 & 7820 & 7720 \\
\hline B-246233 & D-08 & 2.80 & Shells & -10 & 3240 & \pm 40 & 3560 & 3380 & 3450 \\
\hline U-I4787 & D-08 & 2.90 & Shells & -9 & 3020 & \pm 60 & 3370 & 3000 & 3230 \\
\hline U-I4788 & D-09 & 2.60 & Shells & -7.8 & 3451 & \pm 43 & 3835 & 3592 & 3700 \\
\hline U-I4789 & D-II & 0.60 & Shells & -11.5 & 3143 & \pm 33 & 3442 & 3274 & 3370 \\
\hline U- 14790 & D-II & 1.00 & Shells & -11.3 & 1511 & \pm 30 & 1508 & 1340 & 1390 \\
\hline U-|479| & D-II & 1.60 & Plant & -27.7 & 1704 & \pm 29 & 1696 & 1539 & 1610 \\
\hline U-I4792 & D-II & 2.60 & Shells & -8 & 3212 & \pm 34 & 3478 & 3371 & 3420 \\
\hline U-I4793 & D-II & 3.80 & Shells & -7.6 & 3609 & \pm 39 & 4068 & 3834 & 3900 \\
\hline U-I 4794 & D-II & 5.40 & Shells & -7.2 & 3902 & \pm 39 & 4425 & 4183 & 4360 \\
\hline U-I4795 & D-II & 6.00 & Shells & -6.6 & 4274 & \pm 37 & 4869 & 4825 & 4850 \\
\hline U-I4796 & D-II & 6.70 & Shells & -7.1 & 4895 & \pm 36 & 5697 & 5587 & 5600 \\
\hline U-I4797 & D-II & 7.90 & Shells & -5.8 & 4904 & \pm 42 & 5722 & 5587 & 5640 \\
\hline U-14798 & D-II & 9.00 & Shells & -5.9 & 27900 & \pm 200 & 32,720 & 31,520 & 31,910 \\
\hline U-14799 & $D-12$ & 3.60 & Shells & -11.4 & 2501 & \pm 31 & 2735 & 2466 & 2620 \\
\hline U-I4800 & D- 12 & 8.50 & Wood & -29.1 & 863 & \pm 30 & 899 & 726 & 750 \\
\hline U-I480| & D-15 & 5.90 & Shells & 2.3 & 41800 & \pm 900 & 46,400 & 44,100 & 45,230 \\
\hline B-246234 & D-17 & 1.80 & Nut & -9.4 & 1760 & \pm 40 & 1810 & 1560 & 1700 \\
\hline B-246235 & D-17 & 2.70 & Nut & -8.8 & 1890 & \pm 40 & 1920 & 1720 & 1850 \\
\hline B-246236 & D-17 & 5.20 & Shells & -9.8 & 3370 & \pm 40 & 3700 & 3480 & 3630 \\
\hline B-246237 & $D-17$ & 5.40 & Shells & -7.9 & 3430 & \pm 40 & 3830 & 3580 & 3690 \\
\hline B-246238 & D-17 & 5.68 & Shells & -9.1 & 3600 & \pm 40 & 4060 & 3830 & 3900 \\
\hline B-246239 & $D-17$ & 5.70 & Shells & -11.2 & 3930 & \pm 40 & 4510 & 4240 & 4420 \\
\hline B-246240 & D-17 & 6.30 & Shells & -8.5 & 4460 & \pm 40 & 5300 & 4890 & 5200 \\
\hline U-I4802 & $D-18$ & 0.80 & Shells & -11.3 & 1624 & \pm 28 & 1563 & 1416 & 1530 \\
\hline U-I4803 & D-18 & 3.70 & Shells & -13.5 & 3388 & \pm 32 & 3697 & 3564 & 3640 \\
\hline U-I 4804 & D-18 & 4.70 & Shells & -9.4 & 3264 & \pm 30 & 3564 & 3407 & 3470 \\
\hline U-I4805 & D-18 & 5.10 & Shells & -5.5 & 3638 & \pm 49 & 4089 & 3836 & 3940 \\
\hline U-14806 & $D-18$ & 6.10 & Shells & -5.2 & 8072 & \pm 46 & 9088 & 8793 & 9010 \\
\hline B-24624I & D-2I & 1.50 & Shells & -10.6 & 1640 & \pm 40 & 1690 & 1410 & 1540 \\
\hline B-246242 & D-2I & 2.00 & Shells & -11.5 & 1770 & \pm 40 & 1820 & 1570 & 1700 \\
\hline U-I4807 & D-22 & 1.00 & Shells & -10 & 3316 & \pm 34 & 3636 & 3461 & 3560 \\
\hline U-I4808 & D-22 & 1.60 & Shells & -12.5 & 3547 & \pm 35 & 3923 & 3721 & 3840 \\
\hline U-I 4809 & D-22 & 3.80 & Shells & -10.5 & 3423 & \pm 33 & 3820 & 3586 & 3660 \\
\hline U-I48I0 & D-22 & 4.20 & Shells & -7.5 & 3827 & \pm 36 & 4407 & 4094 & 4190 \\
\hline U- $|48| \mid$ & D-22 & 5.20 & Shells & -8.7 & 4253 & \pm 36 & 4862 & 4728 & 4840 \\
\hline U-14812 & D-22 & 7.00 & Shells & -2.5 & 7287 & \pm 44 & 8182 & 8007 & 8120 \\
\hline U- $148 \mid 3$ & D-24 & 1.00 & Shells & -11.3 & 1706 & \pm 5 I & 1718 & 1522 & 1610 \\
\hline U-I48I4 & D-24 & 2.20 & Shells & -11.7 & 1889 & \pm 36 & 1918 & 1727 & 1850 \\
\hline U- $148 \mid 5$ & D-24 & 4.70 & Plant & -27.8 & 886 & \pm 60 & 929 & 685 & 790 \\
\hline U-148I6 & D-24 & 5.70 & Plant & -27.6 & 772 & \pm 40 & 739 & 665 & 690 \\
\hline U- 14817 & D-24 & 7.60 & Plant & -27.1 & 1064 & \pm 91 & 1177 & 787 & 960 \\
\hline U- 14818 & D-24 & 8.95 & Plant & -27.5 & 707 & \pm 35 & 688 & 567 & 670 \\
\hline
\end{tabular}

(Hoogendoorn et al., 2010). Work is currently ongoing to integrate the seismic, lithological and palynological datasets fully. Results of the radiocarbon dating (Table 1 and Figure 6) for the cores studied for palynology give a spread of ages from 9010 (core D-18) to 670 (core D-24) cal. BP.

\section{Surface samples}

Palynological data from the nine surface samples are shown in Figure 7, with ostracod and other microfossil results displayed in Table 2. More or less equal proportions of arboreal pollen (AP) and nonarboreal pollen (NAP) occur across the study region, with highest NAP in the most distal locality (AVD3). AP is represented by abundant Salix and consistently common Pinus, Alnus, Betula, Quercus and several others. NAP components are made up predominantly by Poaceae and Amaranthaceae, which show very similar distributions and abundances, becoming slightly more frequent towards the north (e.g. D-15 core locality). Artemisia is also well represented throughout. Aquatic pollen is present in all samples with increased Sparganium to the north (D-15 core locality) and Potamogeton towards the south (AVD3). Reworked palynomorphs of various ages occur in every sample but are not especially common. Of the NPP, fungal bodies (mainly hyphae) are most frequent in the most landward sites (D-18 and D-15 core localities) that are barren of microfauna. Dinocysts occur in low numbers in all samples but have slightly higher abundances in the southern part of the study area (at and to the south of the D-09 core locality) in the lower delta and avandelta. These include good specimens of $S$. cruciformis, $P$. 


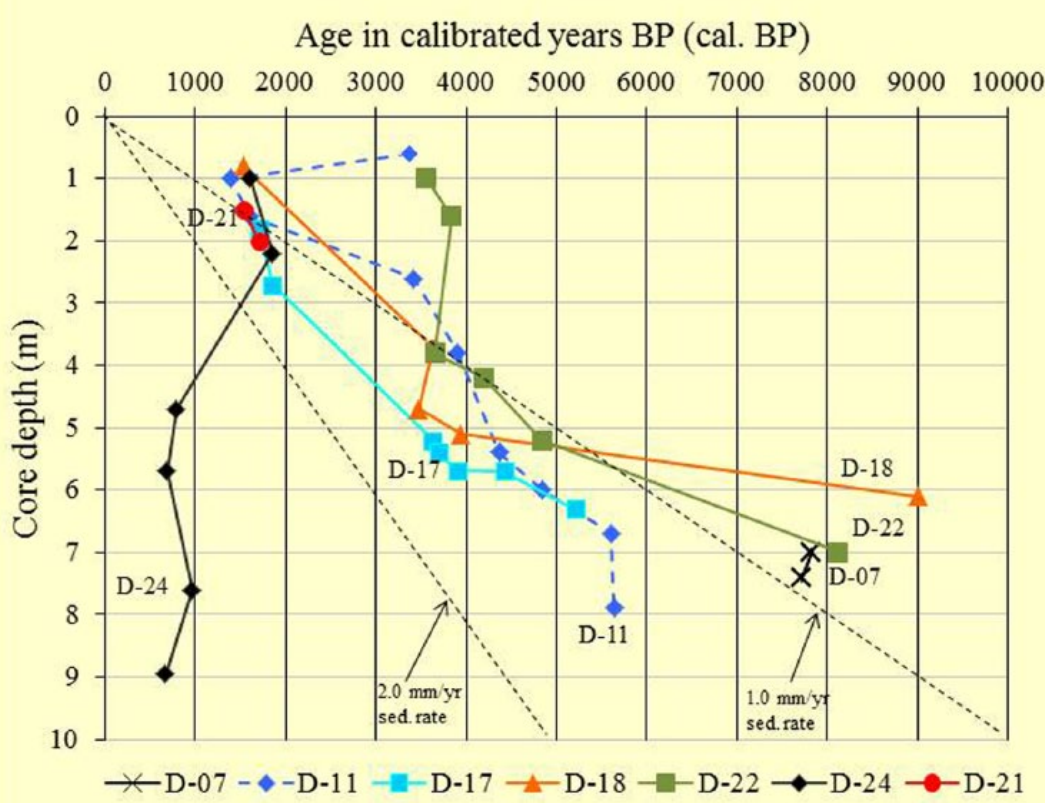

Figure 6. Age-depth plots of radiocarbon ages in calibrated years before present (cal. BP) for selected samples/cores. Data points for cores $\mathrm{D}-08, \mathrm{D}-09, \mathrm{D}-12$ and $\mathrm{D}-15$ are not shown for reasons of diagram clarity.
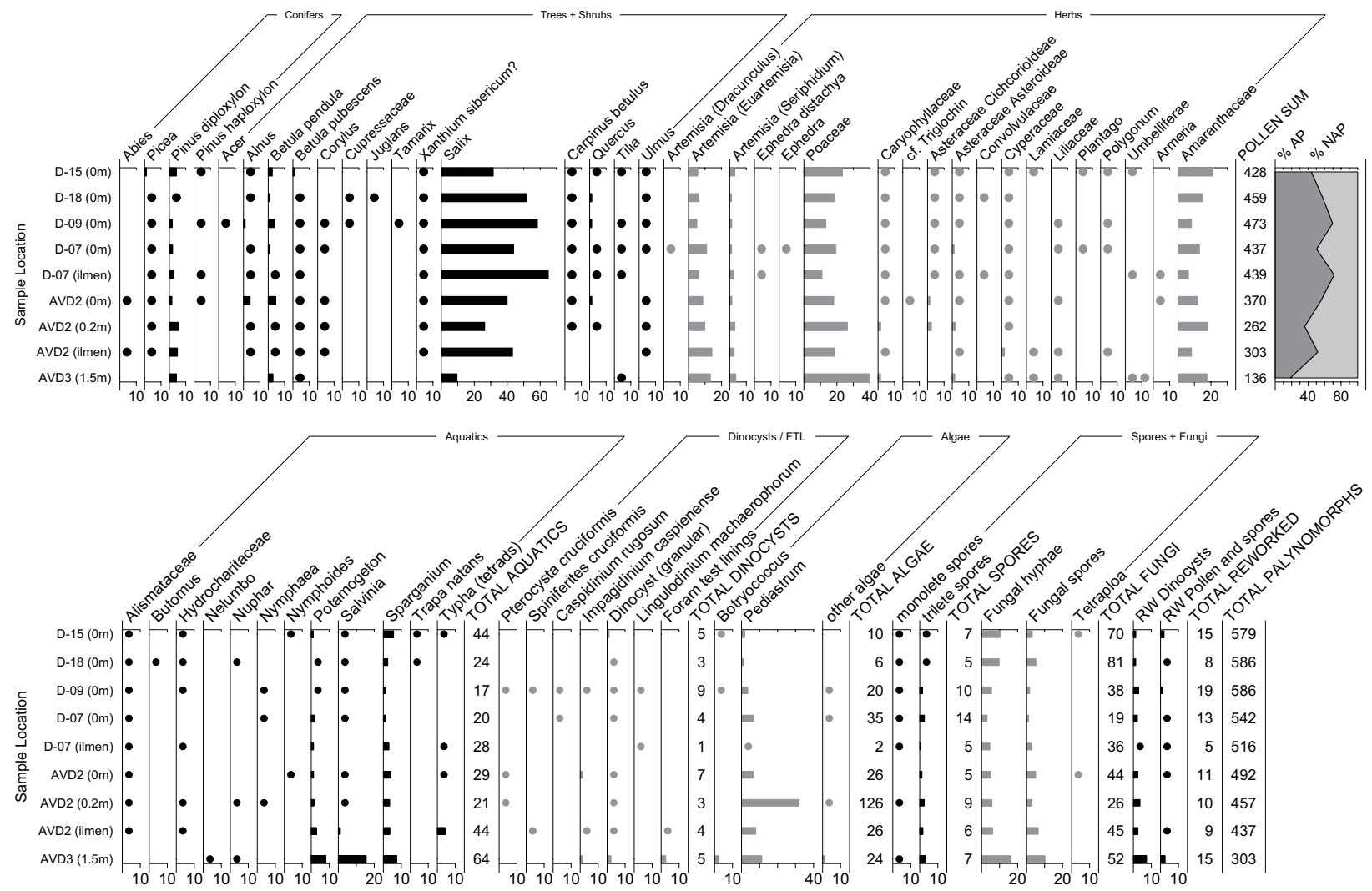

Figure 7. Palynological analysis chart for surface samples collected in the Damchik region. Data for AP and NAP (upper chart) are presented as a percentage of the pollen sum (PS). Data for aquatics and NPP (lower chart) are presented as a percentage of the PS + individual groups. Filled circles denote occurrences of less than $1 \%$. For sample locations see Figure $4 d$.

FTL: foraminiferal test linings; RW: reworked; NPP: non-pollen palynomorphs.

cruciformis, I. caspienense and C. rugosum. A minor peak in representation of I. caspienense occurs at the surface at the AVD2 locality, whereas a sample from $0.20 \mathrm{~m}$ below water level contains abundant Pediastrum. Sample AVD3 (from $1.50 \mathrm{~m}$ water depth) contains frequent Poaceae pollen, mixed aquatic taxa and low numbers of foraminiferal test linings. Ostracod diversity is richest in the more distal samples; AVD2 (ilmen) sample yielded abundant carapaces of Cypridopsis vidua together with a few specimens of Pseudocandona (mainly juveniles). Specimens of Cyprideis torosa, Bacuniella dorsoarcuata and Candona were rare and probably reworked. Sample AVD2 $(0 \mathrm{~m})$ contained a single specimen of Limnocythere inopinata and a juvenile Pseudocandona. Also present but probably reworked were $C$. torosa (common), Leptocythere quinquetuberculata and Caspiolla. Sample AVD2 (0.20m) yielded 


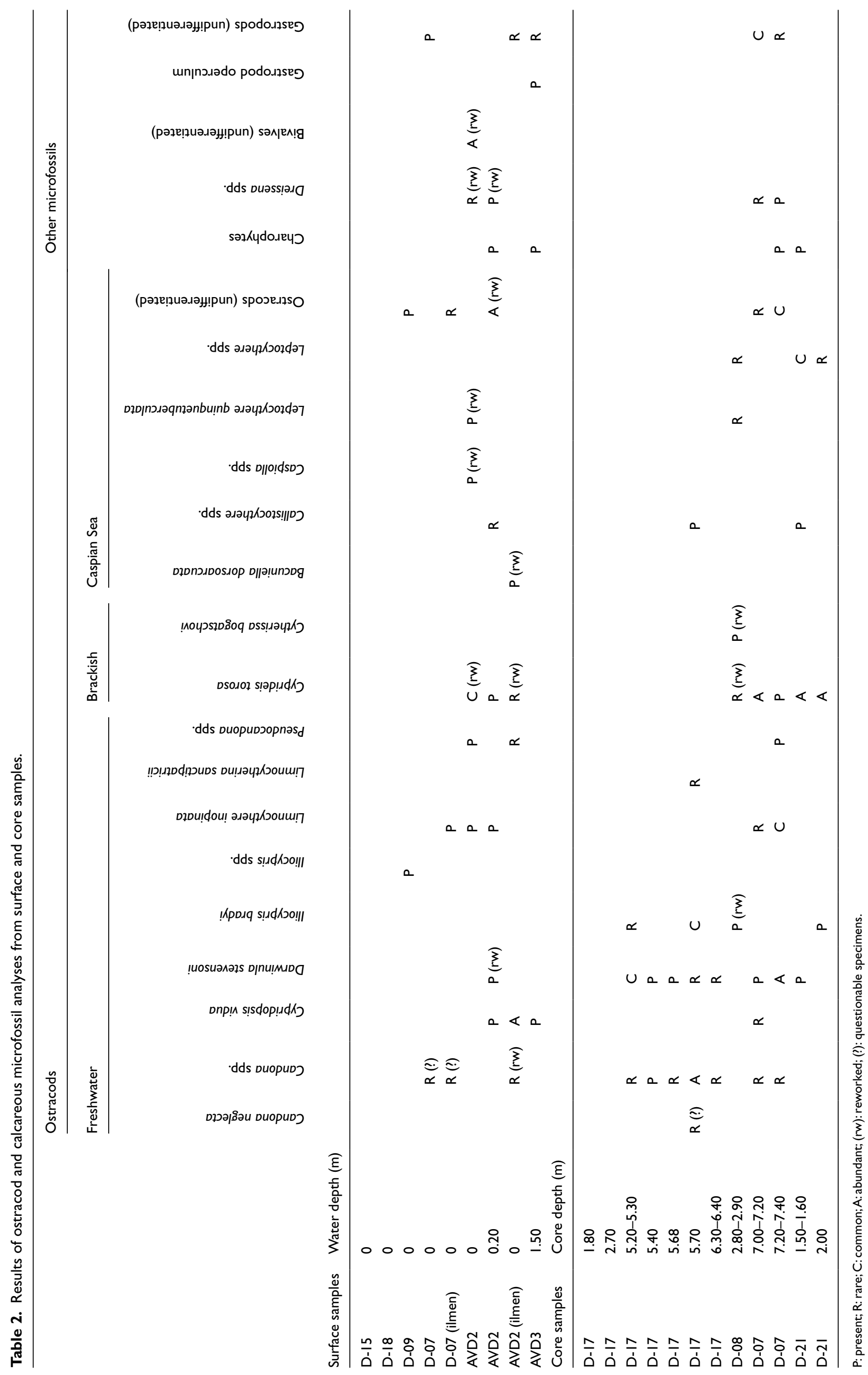


single specimens of L. inopinata, C. vidua, C. torosa and rare Callistocythere, as well as several reworked specimens. Sample AVD3 also contained a single $C$. vidua and several undifferentiated gastropods. Charophyte gyrogonites were recorded in the AVD2 $(0.20 \mathrm{~m})$ and AVD3 samples.

\section{Core samples}

Detailed descriptions of the palynological assemblages recorded in all of the cores studied are provided in the Supplementary Information section, available online, including complete pollen diagrams (Figures S1-S15, available online), lithologies and correlations (Figures S16-S19, available online). Results of ostracod and other microfossil analyses are shown in Table 2.

The majority of the core samples contain rich recoveries of palynomorphs, including mixed assemblages of pollen, spores, algae and dinocysts. The pollen spectra include several types of AP, including Pinus, Quercus, Ulmus, Tilia, Carpinus, Betula, Alnus and Salix. NAP also occurs frequently and includes Poaceae, Artemisia, other Asteraceae and Amaranthaceae. Aquatic pollen from submerged (e.g. Potamogeton) and emergent forms (e.g. Sparganium and Typha) is locally frequent. Algae include Pediastrum and Botryococcus and dinocysts (e.g. I. caspienense, S. cruciformis and P. cruciformis) occur in low but consistent numbers. $P$. cruciformis has not been previously documented from the Caspian Sea, being originally described from the Pleistocene of the Black Sea (Rochon et al., 2002). Also, as reported by Sorrel et al. (2006) from the Aral Sea, specimens similar to Romanodinium areolatum were occasionally observed, and these are included with the counts of $S$. cruciformis. Some of these also closely resemble Galeacysta etrusca, originally described from the late Miocene (Messinian) of the Mediterranean Sea (Corradini and Biffi, 1988) and also known from the early Pliocene of the Pannonian and Dacic Basins (Popescu et al., 2009; Plates 1-3). Fungal bodies are locally frequent. Reworked components include Neogene and Paleogene forms (mainly dinocysts) and Mesozoic and Paleozoic pollen, spores and microplankton.

Representative summary diagrams are shown in Figure 8a-e for pollen and Figure 9a-e for aquatics and NPP. Cores D-07 (Figure 8a) and D-17 (Figure 8b) show good examples of typical pollen distributions, with frequent NAP in the lower sections of the cores and increased AP in the upper parts. Core D-18 (Figure 8c) shows a similar pattern but is almost barren of pollen in the lowermost section, whereas core D-22 (Figure 8d) has a more complete pollen record. The assemblages in core D-24 (Figure 8e) show little significant change within the studied section. Changes in aquatic pollen and NPP assemblages, including reworked elements, are visible in cores D-07 (Figure 9a) and D-09 (Figure 9b). Core D-17 (Figure 9c) shows the presence of frequent freshwater algae (Pediastrum) together with increased numbers of dinocysts, reworked forms, fungal hyphae and aquatic pollen in the upper sections. Core D-18 (Figure 9d) shows similar overall trends, with the additional presence of frequent fungal spores and localized Pediastrum in the lowermost section (where pollen was virtually absent). The aquatic and NPP record from core D-24 (Figure 9e) again shows little overall change throughout.

\section{Interpretation and discussion}

\section{Radiocarbon ages}

The age-depth profiles (Figure 6) show a good deal of consistency between most of the radiocarbon ages from the cored sections. The ages tend to fall in clusters, which might be an indication that gaps in sedimentation have occurred, at least in some parts of the delta. These clusters are 9010-7720 cal. BP, 5640-3230 cal. BP and 1850-670 cal. BP and correspond with the main phases of active delta deposition during the Holocene, as originally shown by Hoogendoorn et al. (2010). Outliers from these main clusters do occur due to reworking and/or sediment inversion. Sedimentation rates will differ between individual cores due to variations in lithology, but have an average of between 1.00 and $1.5 \mathrm{~mm} / \mathrm{yr}$, similar to the rate of $1.3 \mathrm{~mm} / \mathrm{yr}$ estimated by Overeem et al. (2003). The most useful ${ }^{14} \mathrm{C}$ ages are from cores D-07, D-17, D-18, D-22 and also D-11 (not yet studied for palynology). The age-depth plot for core D-24 shows clear evidence for sediment inversion and reworking, which is consistent with the regional setting and palynological and lithological data.

\section{Surface samples}

Pollen data from the surface samples (Figure 7) are broadly comparable with the local and regional vegetation in that proportions of AP and NAP are fairly equally represented. High proportions of Salix pollen are due to the sample locations, most of which are on the river-margin levees where willow forest commonly grows. Sample AVD3 was taken away from the willow forest and has the lowest percentages of Salix pollen, as might be expected as Salix is not a large pollen-producer and the pollen is dispersed both by wind and insects. The remaining AP content is made up of mixed tree taxa such as Alnus, Betula, Carpinus, Quercus, Tilia and Ulmus. Of these, only Quercus and Ulmus grow in the presentday delta (Losev et al. 1998) in the mixed forest areas (see Figure 4c). The pollen from Alnus, Betula, Carpinus and Tilia is, therefore, presumably sourced from outside of the delta region. These are widely dispersed types and also occur in pollen rain and seabed samples in the north Caspian region (Vronsky, 1976). Pinus accounts for less than $10 \%$ of the AP component in the Damchik surface samples and could be wind-blown or water-transported from within the Volga catchment. NAP components, in particular Poaceae, Artemisia and Amaranthaceae, generally occur at frequencies of around $20 \%$ or less of the PS in the surface samples, and these are also likely to be sourced from herbaceous associations within the delta itself, or wind-blown from the adjacent steppe and semi-desert areas. The highest proportions of Poaceae (c. $40 \%$ of the PS) occur in AVD3, and much of this is probably derived from reedbeds, where Phragmites is abundant. Pollen components within the surface samples are therefore thought to be representing pollen sourced mainly from the local area (i.e. the delta) and the adjacent steppe and semi-desert vegetation, but with part of the AP component resulting from long-distance transport. Aquatic pollen and spores also reflect the local delta vegetation in that Sparganium (emergent) is common in the most northerly (drier) locality (D-15), whereas Potamogeton and Salvinia (submerged/floating) are most frequent in the most distal locality (AVD3), where a single occurrence of Nelumbo pollen was also recorded. The parent plant, although very frequent in the lower delta, is insect pollinated and therefore under-represented in pollen profiles.

Dinocyst records provide some new information about the geographic ranges and perhaps environmental tolerances of several taxa. I. caspienense, C. rugosum, S. cruciformis and P. cruciformis all occur in low numbers in samples taken from the partially flooded areas of the lower delta (to the south of core D-09 locality), suggesting that this part of the delta may be influenced by occasional brackish incursions, or that the dinocysts observed are tolerant of extremely low salinity to fully freshwater conditions. An unknown form (a granular cyst with an apical archaeopyle; Plate 2) occurs further north still (at the core D-15 locality) and may, therefore, be a freshwater cyst. Rare occurrences of L. machaerophorum were noted in the midpart of the study area (core D-07 and D-09 localities), where salinity is almost zero. This species is tolerant of a wide variety 

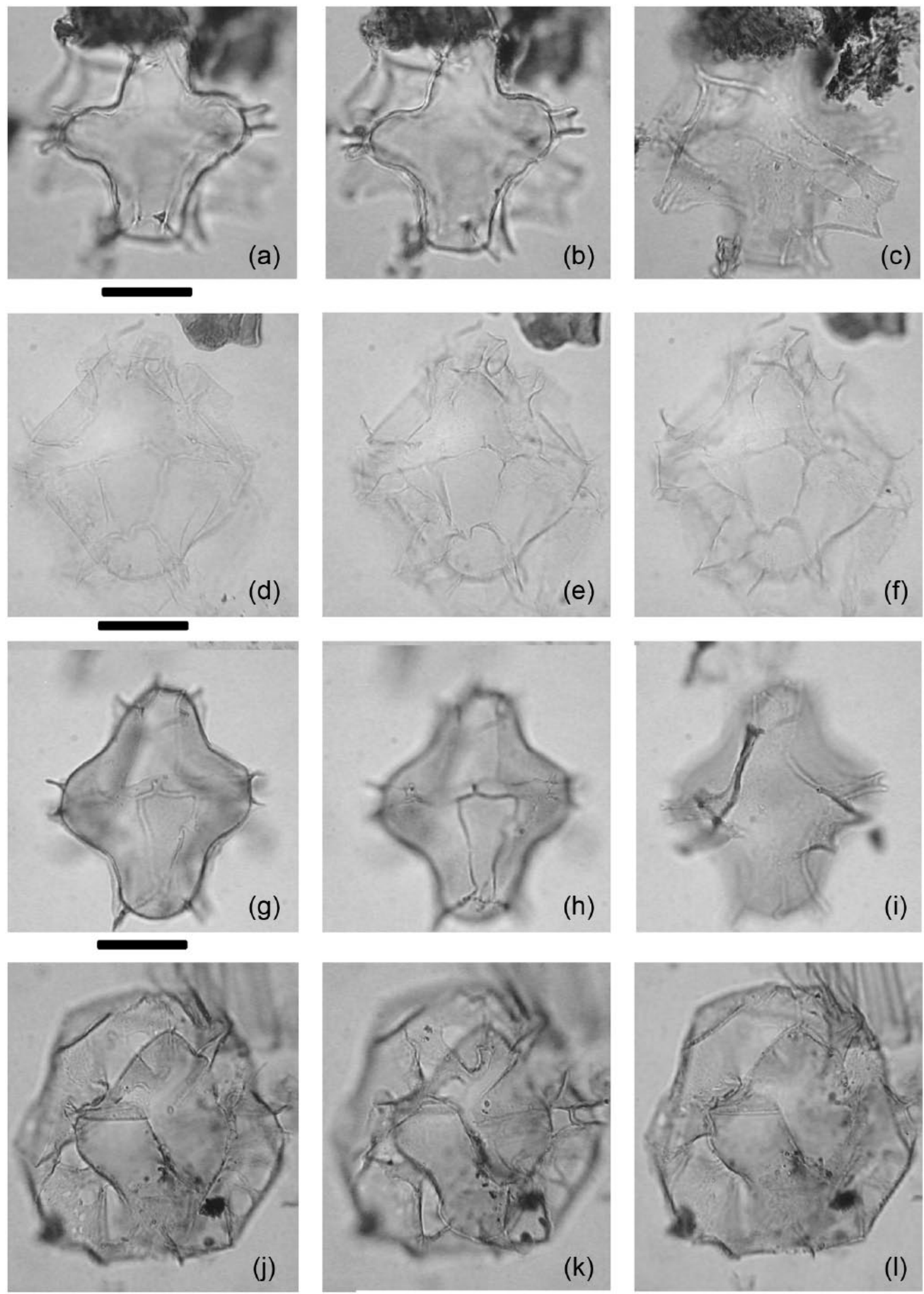

Plate I. Photomicrographs of dinoflagellate cysts from the Damchik locality (surface samples and cores). The scale bar $=20 \mu \mathrm{m}$ (all photos). (a-c) Spiniferites cruciformis (Wall et al., 1973), AVD2 (ilmen). (d-f) S. cruciformis (Wall et al., 1973), Core D-07 (6.90-7.00 m). (g-i) S. cruciformis (Wall et al., 1973), Core D-07 2.90-3.00 m. (j-l) S. cruciformis (Wall et al., 1973), extreme morphotype, similar to Galeacysta etrusca complex (see Popescu et al., 2009), Core D-24 (7.70-7.30m).

of salinities (e.g. Mertens et al., 2012), but it is unlikely to occur naturally in fully freshwater conditions, and these occurrences may be due to reworking, brackish incursions or wind-blown water surges. A peak representation of Pediastrum (at AVD2 $0.20 \mathrm{~m}$ ) suggests a likely ilmen origin for the sample. Freshlooking foraminiferal test linings occur in the most distal sample
(AVD3) with a probable reworked occurrence in the AVD2 (ilmen) sample, and suggest slightly increasing salinity in the avandelta region.

The overall species composition of pollen and dinocysts from the surface samples is similar to that obtained from many of the core samples studied, in particular those deposited since 


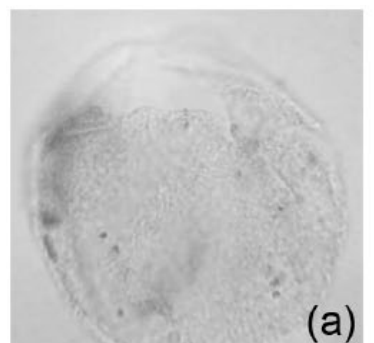

(a)
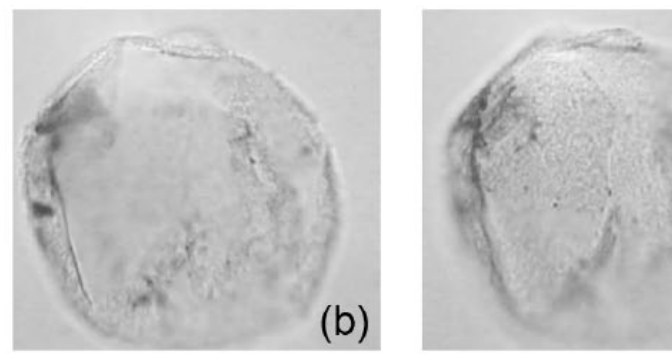

(c)

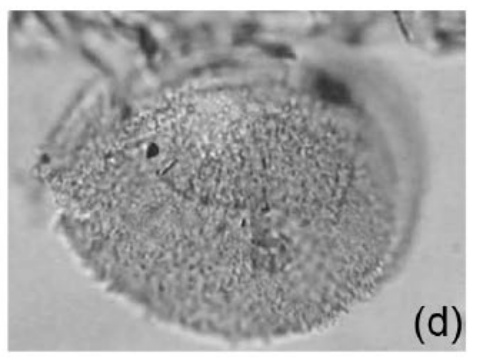

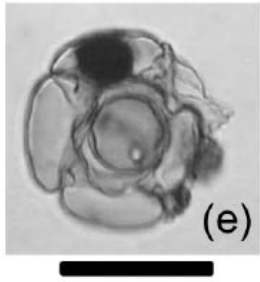
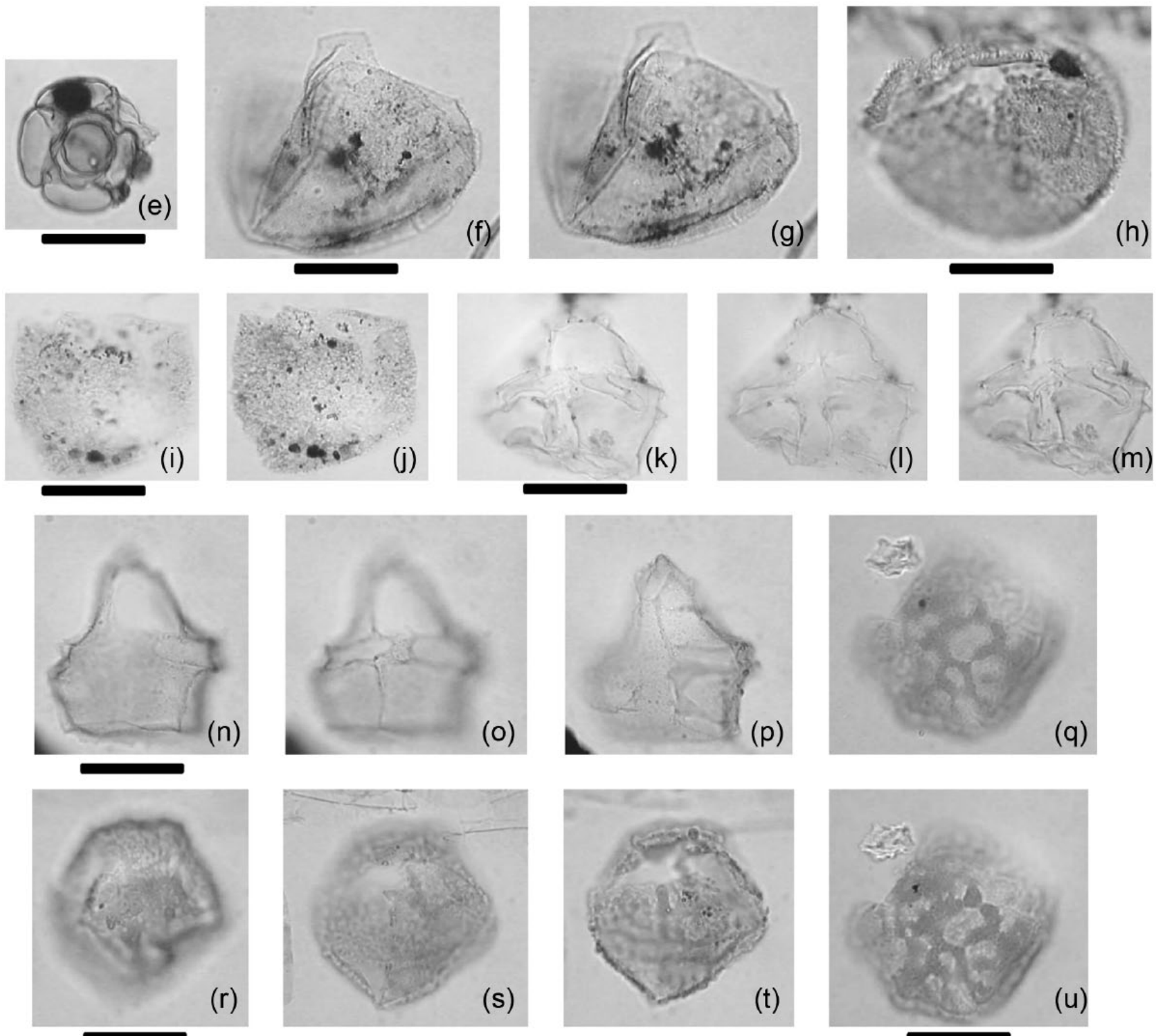

Plate 2. Photomicrographs of marine palynomorphs from the Damchik locality (surface samples and cores). The scale bar $=20 \mu \mathrm{m}$ (all photos). (a-c) indeterminate granular dinocyst, D-07 locality, (surface sample). ( $\mathrm{d}$ and $\mathrm{h}$ ) indeterminate granular dinocyst, D-I 5 locality (surface sample). (e) microforaminiferal test lining,AVD3 locality, 'avandelta' mud ( $1.50 \mathrm{~m}$ water depth). ( $\mathrm{f}$ and $\mathrm{g}$ ) indeterminate granular dinocyst, D- 15 locality (surface sample). (i) and (j) indeterminate granular dinocyst, AVD2 locality (0.20 m water depth). The 'indeterminate granular cysts' have varied ornamentation ranging from even 'granules' (e.g. ( $\mathrm{i}$ and j)) to small 'spines' (e.g. ( $\mathrm{d}$ and $\mathrm{h}$ )). They appear to have an apical archaeopyle, often with attached plates or operculum, similar to Batiacasphaera and the 'baggy cysts' of Traverse (1978). (k-m) Impagidinium caspienense (Marret et al., 2004) AVD2 locality (surface sample). (n-p) I. caspienense (Marret et al., 2004), morphotype similar to the freshwater form Gonyaulax apiculata, and also spiny forms of Spiniferites inaequalis (Wall et al., 1973) Core D-24 (0.40-0.60 m). ( $r-t)$ Caspidinium rugosum (Marret et al., 2004), small specimen, Core D-24 (3.10-3.50 m). (q and u) C. rugosum (Marret et al., 2004), fragment of typical, larger specimen, Core D-24 (I.70-2.00 m).

around $4000 \mathrm{BP}$, suggesting that the pollen and dinocyst spectra obtained, both in core and at the surface, are giving accurate representations of the delta vegetation and deltaic environments. The findings are comparable with previous modern pollen studies from the north Caspian region, such as Vronsky (1976) and Bolikhovskaya and Kasimov (2008). There is no clear evidence that a large proportion of the pollen in the surface samples, except probably Pinus and low numbers of several other 

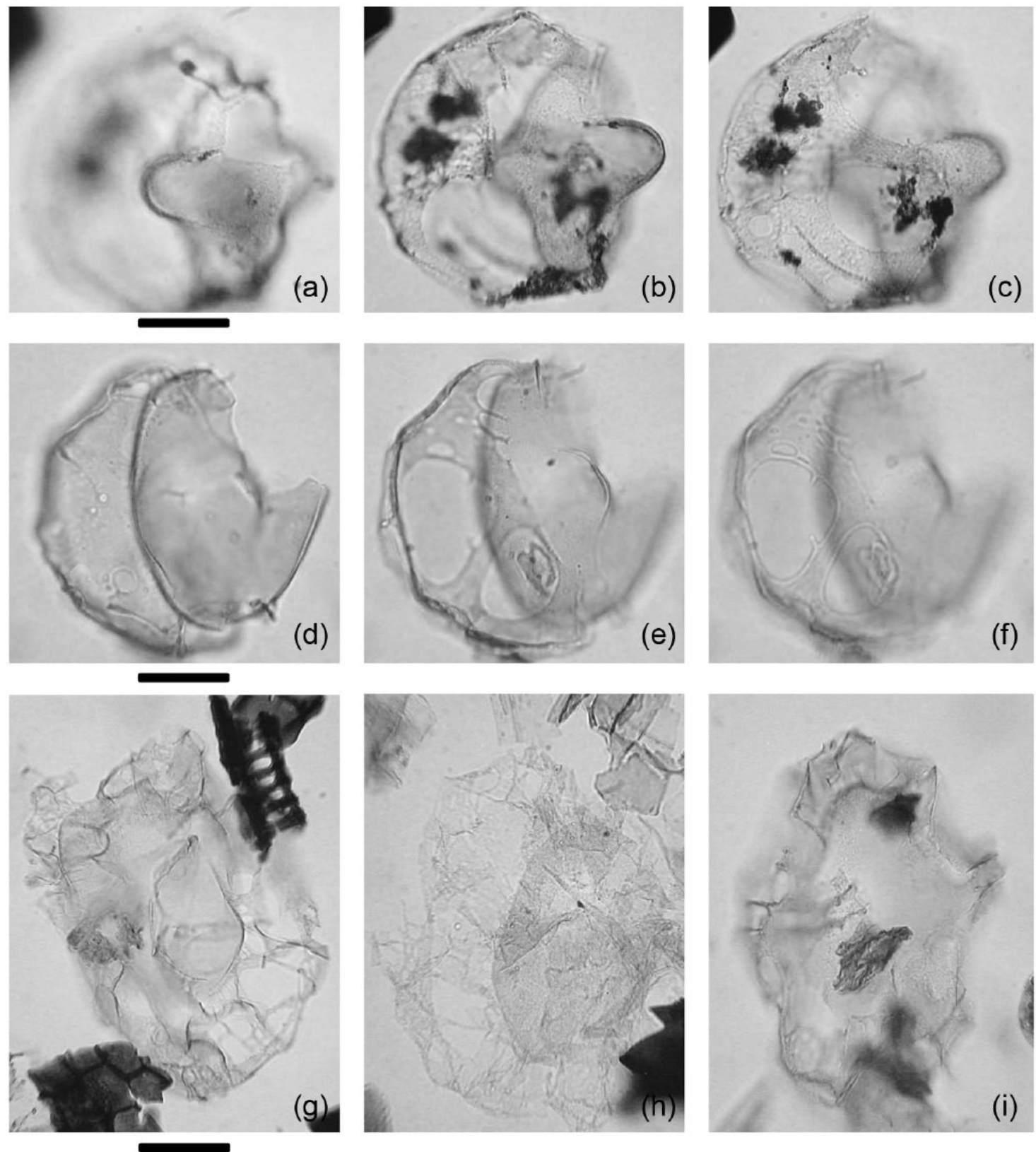

Plate 3. Photomicrographs of dinoflagellate cysts from the Damchik locality (surface samples and cores). The scale bar $=20 \mu \mathrm{m}$ (all photos). (a-c) Pterocysta cruciformis (Rochon et al., 2002), AVD2 locality (surface sample). (d-f) P. cruciformis (Rochon et al., 2002), Core D-2I (3.50$3.60 \mathrm{~m}$ ). (g-i) Spiniferites cruciformis (Wall et al., 1973), end-member morphotypes; $(\mathrm{g})$ from Core D-24 (7.70-7.30 m) shows some similarity with Thalassiphora balcanica (Baltes, 197I) and (h and i) from Core D-24 $(5.90-6.30 \mathrm{~m}$ and 7.00-7.30 m) with Galeacysta etrusca complex (see Popescu et al., 2009).

AP taxa, for example, Carpinus, have been carried over very large distances by wind or water. In general, the results are comparable with the findings of Cambon et al. (1997) in the Rhône delta in that the pollen in the surface samples includes mixed wind dispersed (atmospheric) and fluvially transported components, depending on the sample locations. Low numbers of reworked forms do occur in the Volga delta surface samples, which must be sourced from the Russian hinterland and transported by water.

The Damchik surface samples also contained varying proportions of in situ and reworked ostracods. Autochthonous specimens were fresh in appearance, often preserved as carapaces and some retained soft body parts. Abraded specimens were interpreted as allochthonous, either transported penecontemporaneously from adjacent environments or reworked from older Quaternary deposits. Pseudocandona, Limnocythere, Candona, Darwinula and Iliocypris are all freshwater taxa and found at various locations within the studied area. $C$. vidua, which occurs in several samples and is abundant in the AVD2 (ilmen) sample, typically inhabits well-oxygenated, permanent water bodies rich in vegetation (Meisch, 2000), whereas charophyte gyrogonites indicate proximity to shallow freshwater or brackish pools at the AVD2 $(0.20 \mathrm{~m})$ and AVD3 localities. The presence of $C$. torosa and Callistocythere in AVD2 $(0.20 \mathrm{~m})$ also suggests a degree of brackish influence. Taxa such as Leptocythere, Caspiolla, Bacuniella and Loxoconcha (present in several of the AVD2 and AVD3 samples) are all typical Caspian Sea taxa with brackish-marine affinities and are most probably reworked. Samples from the most landward locations, close to cores D-15 and D-18, were devoid of any microfossil content. The ostracod assemblages in the surface samples are comparable with the palynological observations, and indicate mainly freshwater conditions in the delta region with minor brackish influences in the most distal lower delta and avandelta localities. 


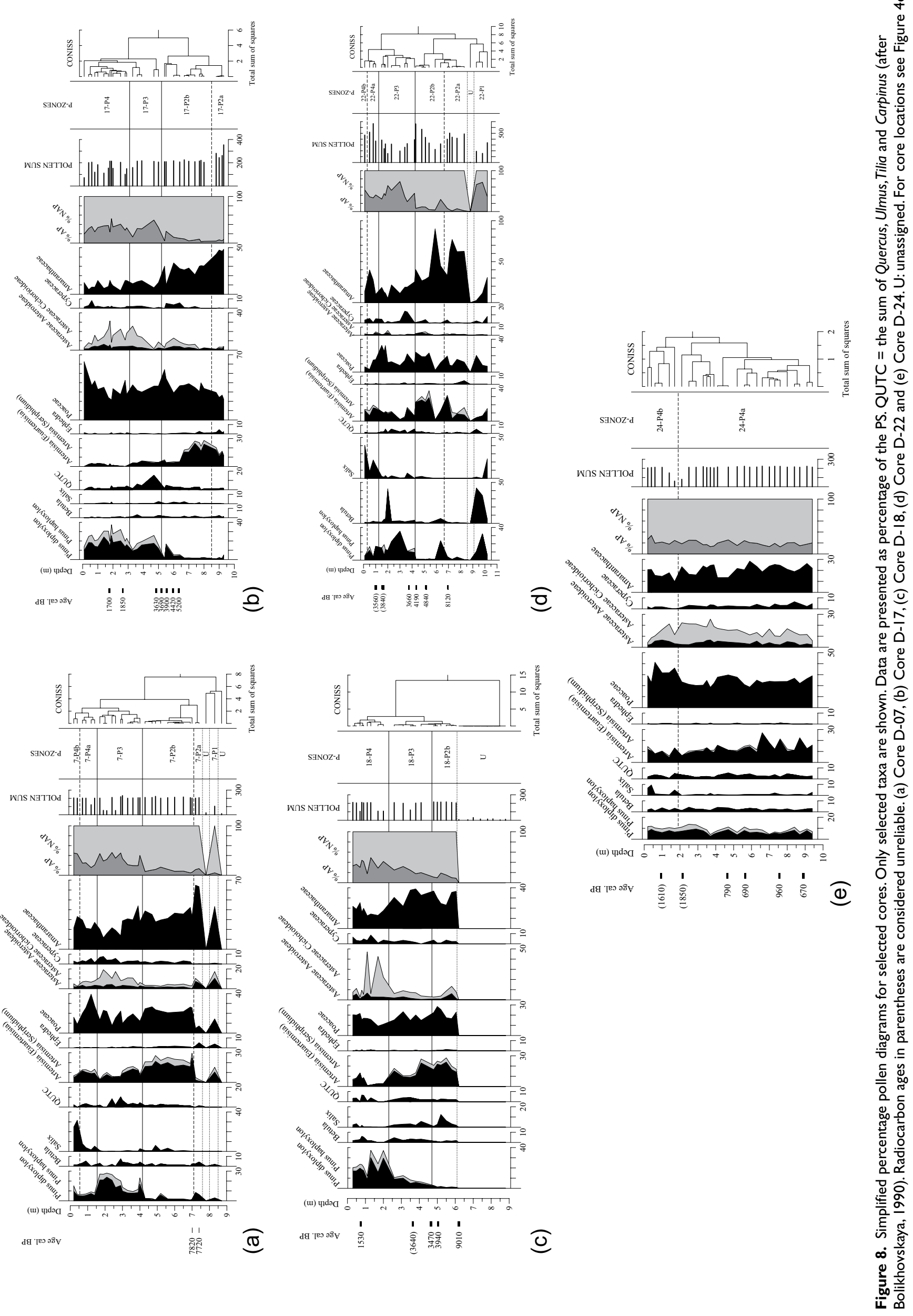



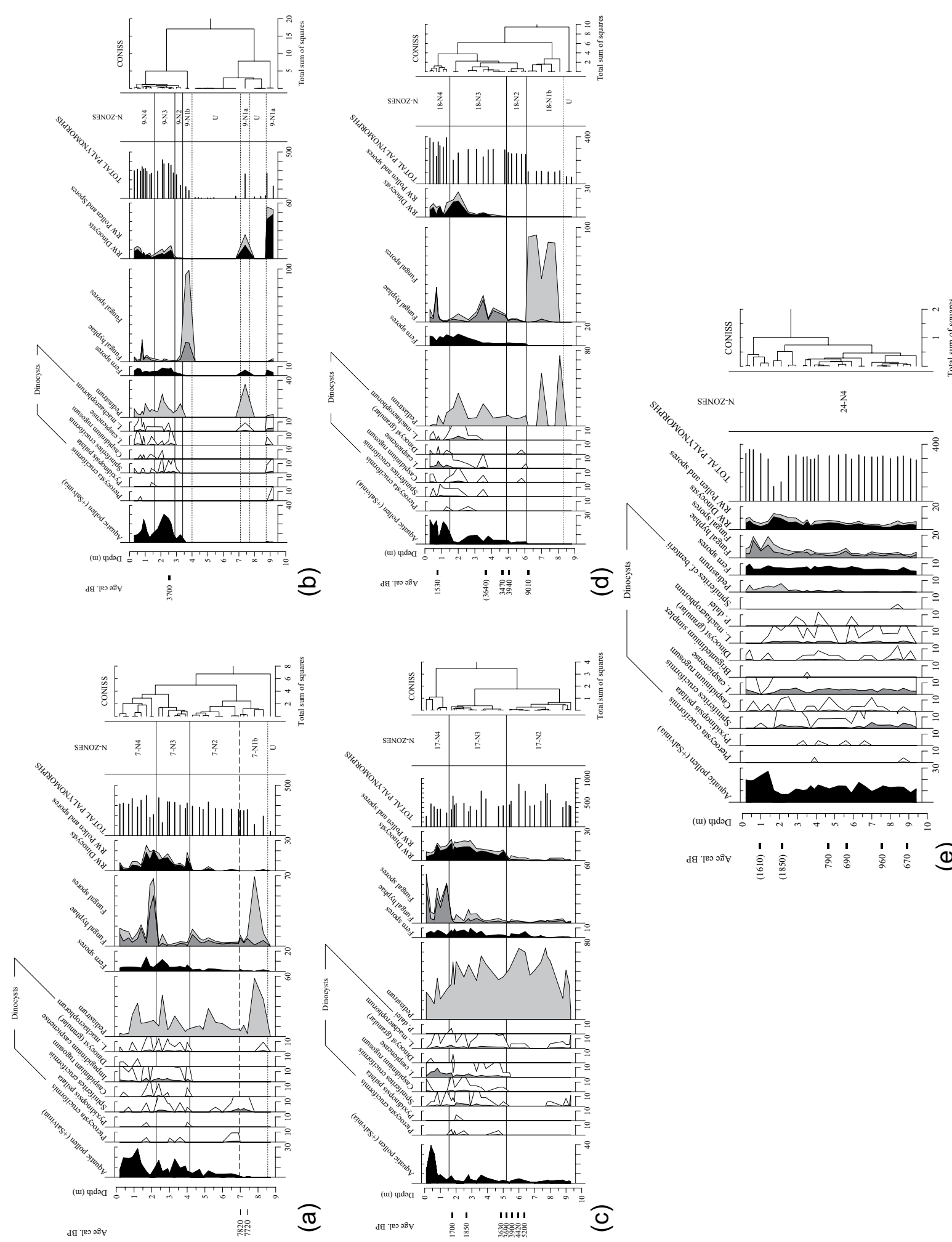

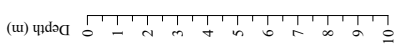

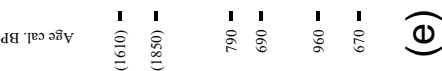




\section{Core samples}

The CONISS zonations based on the pollen and NPP records from the eight studied cores indicate that at least four principal $\mathrm{P}$ zones (P1, P2, P3 and P4) and $\mathrm{N}$ zones (N1, N2, N3 and N4) can be recognized. $\mathrm{P} 2$ can be further sub-divided into sub-zones $\mathrm{P} 2 \mathrm{a}$ and $\mathrm{P} 2 \mathrm{~b}$, and $\mathrm{P} 4$ can be sub-divided into sub-zones P4a and $\mathrm{P} 4 \mathrm{~b}$. Sub-zones N1a and N1b are also recognized. As the $\mathrm{P}$ and $\mathrm{N}$ zonations are based on separate CONISS sums, it is to be expected that the zone boundaries are not always coincident. The $\mathrm{P}$ zones give an indication of changes in the land vegetation, whereas the $\mathrm{N}$ zones illustrate environmental changes in the delta and aquatic realm. In most instances, however, the $\mathrm{P}$ and $\mathrm{N}$ zones occur in a consistent manner, and the principal boundaries usually coincide with lithological changes and are further constrained by radiocarbon ages. Additional information from ostracod and calcareous microfossil studies is included within the $\mathrm{N}$ zone descriptions.

Zone PI. The basal sections of all cores, apart from D-17 and D-24, contain sandy sediments and some also show signs of reddish colouration caused by sub-aerial exposure. For those reasons, pollen recovery is reduced or low in several samples. The same samples, however, invariably contain better recovery of NPP, in most cases of fungal bodies or reworked elements. No single sample is entirely barren of palynomorphs, but several are excluded from the CONISS and consequently have no zone assignments, for example, in the lowermost section of core D-18 (Figure $8 \mathrm{c}$ ). Zone $\mathrm{P} 1$ is assigned within the basal sections of cores D-07 (Figure 8a), D-08, D-09 and D-22 (Figure 8d) and is characterized by low diversity pollen assemblages. Frequent AP is present, mostly consisting of Pinus and locally Betula (including $B$. cf. nana), Salix and Picea (e.g. in core D-22), whereas NAP components include locally common Amaranthaceae, Poaceae and Asteraceae. The pollen compositions point to coniferous and birch forest present regionally and desert-steppe/desert vegetation present in the coastal areas by the delta. Cool and alternating humid/arid climatic conditions are suggested. The basal section $(10.00-8.50 \mathrm{~m})$ in core D-21 is assigned questionably to zone P1. High numbers of Pinus pollen suggest that boreal forest was present in the catchment and humidity high enough for fluvial discharge and localized sand deposition. Further investigation is required, but the section in core D-21 is interpreted as a channel succession.

Zone $P 2$. Zone $\mathrm{P} 2$ is inferred in all studied sections, except core $\mathrm{D}-24$, and is not identified in core D-21. Sub-zone P2a is characterized by the highest abundances of Amaranthaceae pollen and is present as an interval of $2 \mathrm{~m}$ or less in thickness in cores D-07 (Figure 8a), D-17 (Figure 8b) and D-22 (Figure 8d). The pollen data suggest that halophytic and/or xerophytic vegetation extended over large areas in the delta region, most probably in response to aridification and cooling. The distribution of sub-zone $\mathrm{P} 2 \mathrm{a}$ is irregular over the study region, and it is likely that the sediments were deposited in topographic lows away from or in between the Baer hills, which would have had a major influence on sediment distribution. Radiocarbon results from sub-zone P2a give ages within the range of $8120 \mathrm{cal}$. $\mathrm{BP}$ (in core $\mathrm{D}-22$ ) to 7720 cal. BP (in core D-07). Sub-zone P2b is present in all of the studied cores, with the exception of D-24 and D-21. The assemblages vary across the study area but are typified mainly by high frequencies of NAP, especially Artemisia, Poaceae and Amaranthaceae. Localized pulses of AP such as Pinus, Betula and Quercus also occur (e.g. in core D-22), and Salix pollen is locally common in cores D-07 (Figure 8a) and D-18 (Figure 8c). The pollen records suggest that steppe vegetation occurred extensively around the delta region at this time, but with expansion of temperate woodland during periods of warmer and more humid climate. The minor peaks of Salix occur in mud-prone intervals, suggesting that these sections in cores D-07 and D-18 formed under or close to levees, similar to those of the present-day. Subzone $\mathrm{P} 2 \mathrm{~b}$ is constrained by several ${ }^{14} \mathrm{C}$ ages giving an age range of at least 5200-3900 cal. BP in core D-17.

Zone P3. Zone P3 is present in all of the cored sections except D-24. The pollen records are characterized by increased AP, including Pinus and Betula, with Quercus, Ulmus, Tilia and Carpinus (the 'QUTC' group of Bolikhovskaya, 1990) consistently present. However, NAP is still dominant in most samples, with Amaranthaceae, Artemisia, Poaceae and Asteraceae well represented. The dominance of NAP suggests that semi-desert, steppe and salt-marsh vegetation was widely present in the region, whereas the higher occurrences of AP, including warm temperate taxa, for example, in cores D-07 (Figure 8a), D-09, D-17 (Figure $8 \mathrm{~b}$ ) and D-22 (Figure 8d), suggest that forest or woodland vegetation also occurred within or close to the delta. The most likely interpretation is that climates at this time were mostly warm, with increased forest and woodland present during humid periods and expansion of non-forest vegetation during drier periods. The most reliable ${ }^{14} \mathrm{C}$ ages indicate an age range of at least 3700 3230 cal. BP for zone P3. A minor hiatus may occur at the base of $\mathrm{P} 3$, suggested by a terrace in the ${ }^{14} \mathrm{C}$ curve for core D-17 (Figure 6). A few of the ${ }^{14} \mathrm{C}$ ages are inverted (e.g. in cores D-08 and D-18) and may be indicative of some reworking into the base of zone $\mathrm{P} 3$.

Zone P4. Zone P4 occurs in every one of the studied cores and has a distinct pollen signal. Sub-zone $\mathrm{P} 4 \mathrm{a}$ is assigned in cores D-07 (Figure 8a), D-08, D-09, D-21, D-22 (Figure 8d) and D-24 (Figure $8 \mathrm{e}$ ) and is characterized by frequent NAP, especially Poaceae and Artemisia, with Asteraceae and Amaranthaceae also locally common. Pinus and Betula are the most frequent AP components. Sub-zone $\mathrm{P} 4 \mathrm{~b}$ is present close to the surface in the cores mentioned above and contains increased numbers of Salix pollen. The pollen association in sub-zone $\mathrm{P} 4 \mathrm{a}$, with frequent NAP, suggests that steppe and semi-desert vegetation occurred in and around the delta region, with boreal coniferous and birch woodland present in the hinterland. The high numbers of Salix pollen in many of the near-surface samples (sub-zone 4b) illustrate that willow forest was growing on the channel levees, as it does at the present time. The intervals in D-17 and D-18, the most landward cores, are assigned only as zone $\mathrm{P} 4$, and contain mixed assemblages of NAP and AP with Salix occurring only rarely. Core D-24 differs from the other sections in that an extended zone P4 is present encompassing the whole of the studied section (Figure $8 \mathrm{e})$. Radiocarbon ages indicate a time period of at least 1850 $670 \mathrm{cal}$. BP for zone P4, but it is assumed to extend more or less to the present-day.

Zone NI. Zone N1 is characterized by the presence of common reworked forms (sub-zone N1a) and locally frequent fungal spores and algae (sub-zone N1b). Reddish brown sands and clays in the basal sections of cores D-08 and D-09 (Figure 9b) contain many reworked Mesozoic dinocysts indicative of sub-zone N1a. Although deposition does not often occur in deltaic settings during lowstands, the high proportions of reworked palynomorphs suggest significant downcutting within channel settings, consistent with the reconstructions for the Volga delta region by Rychagov et al. (2010) and Mayev (2010) at the time of the Mangyshlak lowstand. Samples from higher in the sections of cores D-08 and D-09 (Figure 9b) and in cores D-07 (Figure 9a) and D-18 (Figure 9d) are characterized by frequent fungal bodies (mainly spores) and locally common Pediastrum algae (e.g. cores D-07 and D-18) 
and are assigned within sub-zone N1b. Fungal spores and hyphae occur in a wide variety of sediment types but are most often associated with dry conditions (van Geel, 2001), and frequently occur in soils or similar sediments subject to sub-aerial exposure. Fungal spores (as opposed to hyphae) are more likely to occur in wind-blown sediments, as they are largely wind dispersed. They may also be linked with soil erosion (Leroy et al., 2009; Mudie et al., 2011). The algae are probably derived from ilmen. Zones P1 and $\mathrm{N} 1$ together indicate depositional conditions varying between sub-aerial, aeolian, hyper-saline and freshwater lacustrine, as would have occurred in the Baer hills during the Mangyshlak period. The section $10.00-8.50 \mathrm{~m}$ in core D-21 is questionably assigned to zone $\mathrm{N} 1$ and contains frequent reworked palynomorphs, consistent aquatic pollen and locally frequent Pediastrum, consistent with a channel setting. The overlying section, 8.00$4.80 \mathrm{~m}$, consists almost entirely of sand, and has no CONISS assignment as only low numbers of NPP are present. These are mostly algae and reworked forms, also consistent with the presence of channel sands.

Zone N2. Zone N2 is interpreted in cores D-07, D-08, D-09, D-17 and D-18 and is characterized by frequent freshwater taxa. These include rare but consistent aquatic pollen, common and locally abundant Pediastrum algae and low numbers of dinocysts, including S. cruciformis, for example, in cores D-07 (Figure 9a) and D-17 (Figure 9c). The high abundance of Pediastrum in core D-17 is possibly indicative of a former position, or previous greater extent, of Damchik ilmen, which occurs close to the core D-17 locality at the present time. Lesser numbers in other sections are probably picking out smaller delta ilmen. The dinocysts suggest that low salinity to freshwater conditions occurred periodically in the delta at this time, with probable connections to the open waters of the Caspian Sea.

Samples 7.40-7.20 $\mathrm{m}$ and $7.20-7.00 \mathrm{~m}$ in core $\mathrm{D}-07$ gave ${ }^{14} \mathrm{C}$ ages of 7720 and $7820 \mathrm{cal}$. BP respectively. Even though the ages are inverted, the $95 \% 2 \sigma$ ranges overlap, and there is no suggestion of sediment disturbance or reworking. The age range of $7820-7720 \mathrm{cal}$. BP is therefore believed to be valid for the sample interval. Sample 7.40-7.20m contains an ostracod assemblage dominated by typically freshwater forms including Darwinula stevensoni and $L$. inopinata. The sample immediately above, $7.20-7.00 \mathrm{~m}$, is dominated by mainly smooth specimens of $C$. torosa, suggesting brackish conditions, although typically freshwater species $C$. vidua, D. stevensoni and $L$. inopinata are also present rarely. This suggests a change from freshwater to weakly brackish conditions in this short sample interval in core D-07. Predominantly freshwater conditions are indicated by ostracod faunas from core D-17 based on the presence of D. stevensoni, Iliocypris bradyi, Limnocytherina sanctipatricii and Candona in samples with ${ }^{14} \mathrm{C}$ ages of 5200, 4420 and $3900 \mathrm{cal}$. BP.

Zone N3. Zone N3 is also present in all studied sections, apart from core D-24, and is characterized by consistent brackish dinocysts, most notably I. caspienense and S. cruciformis. Localized peak occurrences of Pediastrum also occur in most sections, being especially frequent in cores D-17 and D-21. Aquatic pollen is also present consistently, including Potamogeton, Sparganium and others. Reworked palynomorphs of various ages occur consistently and are sometimes common. The combined presence of dinocysts and algae suggests that deposition occurred in freshwater to low salinity conditions, with periodic connections to open water. Freshwater conditions are indicated by ostracod faunas in core D-17 in samples with ${ }^{14} \mathrm{C}$ ages of 3690 and $3630 \mathrm{cal}$. BP, where D. stevensoni, I. bradyi and Candona were recorded. Fresh specimens of Leptocythere in the more distal core D-08, in a sample giving a ${ }^{14} \mathrm{C}$ age of $3450 \mathrm{cal}$. BP, suggest brackish to open water Caspian influences.
Zone N4. Zone N4 is characterized by varying numbers of aquatic pollen (mainly Potamogeton and Sparganium), common Pediastrum and consistent brackish dinocysts, in particular $I$. caspienense. Fungal bodies, especially hyphae, are also locally frequent, for example, in cores D-07 (Figure 9a) and D-17 (Figure 9c). Two samples from core D-21, with ${ }^{14} \mathrm{C}$ ages of 1700 and $1540 \mathrm{cal}$. BP, contained abundant brackish water ostracods $(C$. torosa) as well as brackish to marine forms (Leptocythere and Callistocythere) and single specimens of the freshwater forms $D$. stevensoni and I. bradyi. Many specimens were very well preserved, containing the remnants of soft body parts, indicating an in situ assemblage with some influence from brackish conditions in the lower delta and avandelta. Samples of similar age (1850 and $1700 \mathrm{cal}$. BP) from the more landward core D-17 were barren of microfauna. The delta environments indicated by the NPP and ostracod data differ across the study area, although the common presence of aquatic pollen, algae and dinocysts is indicative of deposition in freshwater to very low salinity settings, similar to those that occur in the lower delta and avandelta at the present time. Samples with increased aquatic pollen are most likely to indicate a shift in delta deposition in a landward direction, with avandelta aquatic plant associations extending into the lower delta region and kultuk-ilmen environments present. The more northerly core D-17 locality probably had less open water influences at the time of deposition suggested by the absence of ostracods. Samples with frequent fungal hyphae tend to occur in intervals that also contain increased numbers of reworked palynomorphs, and also reduced numbers of aquatic pollen and algae. The hyphae may be derived from soil mycorrizae, and their presence is consistent with periodically dry conditions and soil formation, either during intervals of Caspian Sea relative lowstand or at times when deposition has occurred away from the main fluvial channels. The NPP data from core D-24 show virtually no change throughout, and an extended zone N4 is present. The mixed assemblages suggest a kultuk setting in an incised channel that has subsequently been infilled. The mixing of ${ }^{14} \mathrm{C}$ ages (within a range of 1850-670 cal. BP) supports a channel interpretation (see Figure 6) and suggests that the succession in core D-24 has been influenced by sediment inversion, slumping and reworking. The younger ages, within a $2 \sigma$ range of $1180-570 \mathrm{cal}$. BP, occur in the lower part of the studied section and are based on leaf fossils which are most probably in situ, and these ${ }^{14} \mathrm{C}$ ages are therefore most probably reliable. This age range closely matches the known age of the Derbent lowstand and coincides approximately with the 'Medieval Warm Period' (Kroonenberg et al., 2008).

Phases of delta deposition. Many similarities, and also differences, between the various zones occur in the individual cores, but the principal zones are believed to be more or less synchronous and give an indication of vegetation $(\mathrm{P})$ and environmental (N) responses in the delta during various phases of deposition. They broadly correspond to the main phases of active delta deposition during the Holocene recognized by Hoogendoorn et al. (2010) based on seismic character and lithology, and are referred to in the present study as Delta phases 1, 2, 3 and 4. Delta phase 1 is older than c. 9010 cal. BP and corresponds to zones $\mathrm{P} 1$ and $\mathrm{N} 1$. Delta phase 2 is younger than c. 9010 and older than $3900 \mathrm{cal}$. BP and corresponds approximately to zones P2 and N2. Delta phase 3 is constrained by radiocarbon ages of between 3700 and $3230 \mathrm{cal}$. BP and corresponds approximately to zones $\mathrm{P} 3$ and N3. Delta phase 4 produced ages of $1850 \mathrm{cal}$. BP and younger, and corresponds to zones P4 and N4.

\section{Comparisons with the Volga-Akhtuba floodplain region}

The palynological records obtained from the Damchik cores can be broadly correlated to the palynological vegetation and climate 
scheme (Bolikhovskaya, 1990; Bolikhovskaya and Kasimov, 2010) for the lower Volga at the Solenoe Zajmishche locality in the Volga-Akhtuba floodplain region, to the north (Figure 10). The period 11,500-10,350 cal. BP at Solenoe Zajmishche was characterized by frequent Pinus, Picea and Abies pollen, suggesting forest and forest-steppe vegetation and a relatively cool and humid climate, and conditions at Damchik were probably broadly similar. Increased numbers of Amaranthaceae pollen, and subsequently tree taxa such as Carpinus, Tilia and Ulmus in the period $10,350-8900 \mathrm{cal}$. BP suggest that steppe and forest-steppe were present at the Solenoe Zajmishche locality, and the climate was predominantly dry. Incised valleys and dune fields (Baer hills) were present at Damchik during the Mangyshlak lowstand at around the same time. Maxima of Amaranthaceae pollen suggest cold and dry conditions at Solenoe Zajmishche between 8400 and 8240 cal. BP, and a similar palynological event occurs in Damchik in core D-22 (8.30-7.30 m, sub-zone P2a) occurring just below a horizon with a radiocarbon age of $8120 \mathrm{cal}$. BP. A comparable event in core D-07 $(7.40-7.00 \mathrm{~m})$ produced slightly younger ${ }^{14} \mathrm{C}$ ages of 7720 and $7820 \mathrm{cal}$. BP. It is possible, although unproven, that the Amaranthaceae event at Solenoe Zajmishche and in core D-22 at Damchik may be a response to the so-called ' 8200 BP cold event' which affected much of Europe (Magny et al., 2003; Thomas et al., 2007) and has also been observed in the western Black Sea region (Filipova-Marinova et al., 2013). Pollen evidence from the other cores (e.g. D-07) suggests that dry, but not necessarily cold, conditions continued until at least $7720 \mathrm{cal}$. BP.

Warm climatic events during the mid-Holocene period 6970$4040 \mathrm{cal}$. BP are evident at Solenoe Zajmishche where increased numbers of AP, including Carpinus, Ulmus, Fagus, Tilia, Betula and various conifers indicate that forest-steppe and mixed forest were widespread, whereas NAP elements remained dominant at Damchik (sub-zone P2b), suggesting that steppe vegetation was prevalent close to the delta region. Increased numbers of NAP, including Amaranthaceae, Artemisia and Ephedra occurred at Solenoe Zajmishche in the period 4040-3770 cal. BP which is thought to reflect the expansion of dry steppe and semi-desert vegetation in response to cold and dry climatic conditions (Bolikhovskaya, 1990; Bolikhovskaya and Kasimov, 2010). An equivalent event is not clearly seen in the Damchik pollen records but may be marked by a condensed section or gap in sedimentation: the inferred timing is also close to the $\mathrm{P} 2 / \mathrm{P} 3$ zone boundary. The period from $3770 \mathrm{cal}$. BP to the present-day at Solenoe Zajmishche shows fluctuating but gradually falling proportions of AP suggesting changes in vegetation from forest-steppe to steppe, then from dry steppe to semi-desert, indicating a trend towards generally drier climates (Bolikhovskaya, 1990; Bolikhovskaya and Kasimov, 2010). This is broadly comparable with Damchik in that increased AP (in zone P3) indicates the presence of forest or woodland communities in the delta region. Frequencies of NAP then show further increases (in sub-zone $\mathrm{P} 4 \mathrm{a}$ ), indicating steppe or semi-desert vegetation and presumably drier climatic conditions leading up to the Derbent lowstand period. Subsequently, aquatic pollen records indicate landward expansion of avandelta vegetation (in zone N4). These events probably occurred at a time when the Solenoe Zajmishche locality was subject to alternating warm/humid and cold/dry climatic conditions, with steppe and dry steppe vegetation present.

Ages for the phases of delta deposition observed at Damchik are based on radiocarbon dates from the individual sections studied, although some gaps in the radiocarbon record remain. A more complete picture can be obtained from the inferred correlation with the regional vegetation and climate scheme of Bolikhovskaya (1990) and Bolikhovskaya and Kasimov (2010). Using this correlation, Delta Phase 1 is likely to represent the period of approximately $11,500-8900 \mathrm{cal}$. BP, Delta Phase 2 approximately $8900-3770$ cal. BP, Delta Phase 3 approximately
$3770-2080$ cal. BP and Delta Phase 4 approximately 2080 cal. BP to the present-day (Figure 10).

\section{Caspian Sea level}

Conventional (i.e. uncalibrated) radiocarbon dates, lithological and palynological data from the present study have been used by Kroonenberg et al. (2008) and Hoogendoorn et al. (2010) to produce a new partial sea level reconstruction, which also incorporates lowstand data from the Kura delta (Hoogendoorn et al., 2005) and highstand data from Dagestan (Kroonenberg et al., 2007). This is generally in agreement with other published studies (e.g. Rychagov, 1997), in that a major lowstand episode (the Mangyshlak event) occurred in the early Holocene before c. 9000 BP. Subsequently, Caspian Sea levels were variable in the early to mid-Holocene, but with a rising trend (at least in the northern Caspian Sea), reaching a peak at around 2600 BP (Kroonenberg et al., 2007), coincident with the beginning of the humid Subatlantic period in Western Europe (van Geel and Renssen, 1998). The palynological results from the Damchik cores (this study) are in broad agreement with these findings, although it is clear that there are regional differences during the Holocene and these remain only partially explained.

For the period 11,500-8900 cal. BP (Delta Phase 1, zones P1 and N1), palynological data from Damchik are mostly consistent with relatively low Caspian Sea levels, with the dominant assemblages indicative of erosional and sub-aerial conditions, as would have occurred during the Mangyshlak lowstand. Following the relative lowstand, a small rise in Caspian Sea level, perhaps in association with wind-blown surges, would have easily flooded over the delta front areas, and probably occurred at the onset of Delta Phase 2 (zone P2 and N2) at around $8900 \mathrm{cal}$. BP, suggested the presence of low numbers of brackish dinocysts, for example in core D-07 (Figure 9a) and core D-18 (Figure 9d). A cold and dry period (sub-zone P2a) then occurred, possibly related to the ' 8200 year cold event', which may have coincided with a fall in Caspian Sea level interpreted by Varushchenko et al. (1987) at around the same time. Pollen composition in the remainder of Delta Phase 2 is dominated by NAP with freshwater algae (Pediastrum) occurring frequently and dinocysts rarely; these are consistent with generally high Caspian Sea levels and kultuk-ilmen deposition. The high levels of NAP are likely to have been sourced from steppe and reedbeds. Dinocyst evidence from the central and southern Caspian Sea regions also suggests that early to mid-Holocene Caspian Sea levels were mainly high, with highest levels being reached prior to c. 4000 cal. BP, coinciding with maximum abundances of the dinocysts $P$. psilata and I. caspienense, caused by increased glacial melt-water from the Pamir Mountains via the Uzboy and Amu-Darya river systems (Leroy et al., 2007, 2013a). The end of Delta Phase 2 at Damchik occurs at more or less the same time as a cold and dry episode interpreted at around $4000 \mathrm{cal}$. BP at Solenoe Zajmishche (Bolikhovskaya and Kasimov, 2010). This event is not discernible in the Damchik pollen records, but it may be represented as a hiatus or break in sedimentation (between zones P2/N2 and P3/N3).

The onset of Delta Phase 3, at around 3770 cal. BP, is represented in the palynological records by increased AP, increased reworking and more frequent dinocysts (especially I. caspienense). It is likely that this was a period with variable Caspian Sea levels; warm and humid conditions in the catchment (Bolikhovskaya and Kasimov, 2010) would have enabled significant Volga runoff, leading initially to a Caspian Sea rise, followed by a period of fall, with an outbuilding of the delta allowing colonization of the delta plain by arboreal species. There is no positive evidence that the '2600 BP highstand' (Kroonenberg et al., 2007) is represented in the delta palynological records; it could be 


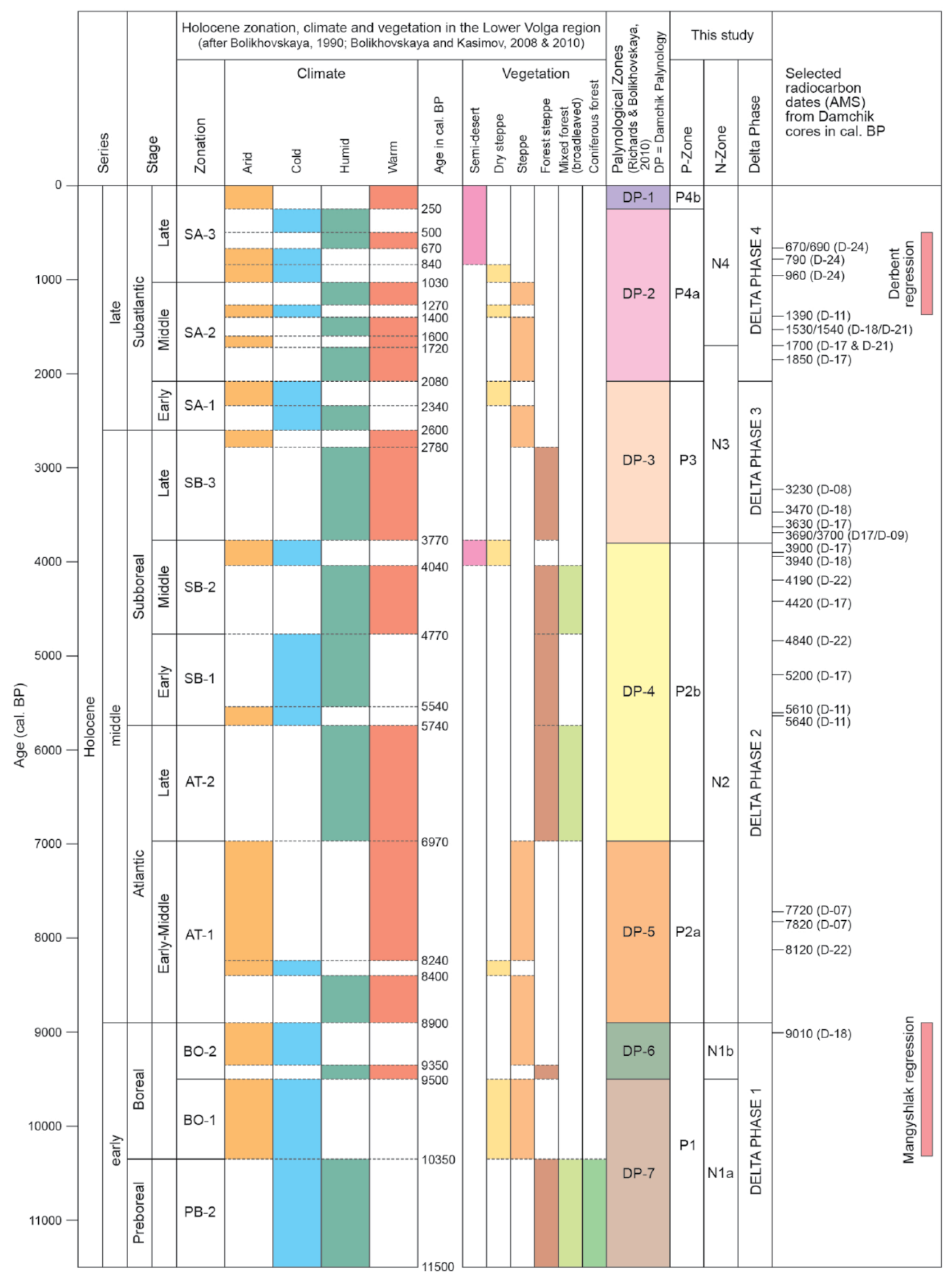

Figure 10. Holocene stages, vegetation and climate in the lower Volga region (after Bolikhovskaya, 1990; Bolikhovskaya and Kasimov, 20I0; Richards and Bolikhovskaya, 2010) and correlation to delta phases and pollen (P) and non-pollen (N) zones in the present study. AMS: accelerated mass spectrometry.

represented by one of the peaks in aquatic (avandelta) taxa (e.g. in core D-08 at $2.10 \mathrm{~m}$ ), but there is no specific age information to confirm this.
The period from 2080 cal. BP to the present-day (Delta Phase 4) is also likely to have been a period of varying Caspian Sea levels, with an initial rise indicated by increased aquatic pollen 
and freshwater algae in several cores after c. 2080 cal. BP, followed by increased NAP and fungal bodies associated with the Derbent lowstand event, which is well documented from around the northern Caspian region. Caspian Sea level is thought to have dropped to at least $3 \mathrm{~m}$ (Rychagov, 1997; Rychagov et al., 2010) or perhaps $20 \mathrm{~m}$ or more (Kroonenberg et al., 2008) below its present level at this time. This event is clearly evident in the palynological records from core D-24 where an incised channel succession is dated at between 1180 and 570 cal. BP, more or less time-equivalent to the 'Medieval Warm Period' (Kroonenberg et al., 2007, 2008). A major increase in aquatic pollen is evident in all of the studied cores towards the top of zone N4, indicating landward expansion of the avandelta associations once again. This is likely to have occurred within the last few hundred years and probably represents recent rises in Caspian Sea level coincident with the 'Little Ice Age' (Badukova and Kalashnikov, 2010; Kroonenberg et al., 2007) and also observed by Leroy et al. (2011) and Naderi Beni et al. (2013b) in the southern Caspian region.

\section{Comparison with the Mio-Pliocene palaeo-Volga delta}

The modern Volga delta is a partial analogue for the Mio-Pliocene palaeo-Volga delta (Abdullayev et al., 2012; Kroonenberg et al., 2005), which contains large oil and gas reserves in the central and south Caspian basins, more than $500 \mathrm{~km}$ to the south of the present-day delta, in sediments of the Productive Series (Reynolds et al., 1998). The palaeo-Volga was much larger than the presentday delta and deposited mainly clastic sediments up to $c .6000 \mathrm{~m}$ or more in thickness over a period of about 2.6 Myr (Abdullayev et al., 2012) in the latest Miocene and Pliocene. Depositional models and generalized stratigraphy for the Productive Series are presented by Abdullayev et al. (2012), Abreu and Nummedal (2007), Baganz et al. (2012), Green et al. (2009), Hinds et al. (2004) and others. During the late Miocene (Pontian), the Caspian Sea was connected to the Para-Tethyan oceans (Reynolds et al., 1998). Subsequently, between 6 and c. $5.3 \mathrm{Myr}$, a major baselevel fall of approximately $1500 \mathrm{~m}$ (Abdullayev et al., 2012) resulted in the formation of the palaeo-Volga canyon. This is incised more than $500 \mathrm{~m}$ below the present ground level and can be traced almost $2000 \mathrm{~km}$ northwards from the mid-Caspian region into the Russian platform (Kroonenberg et al., 2005). The isolated south Caspian basin was then rapidly re-filled with fluvio-lacustrine sediments, initially with Lower Productive Series deposits during the latest Miocene to Pliocene, followed by the Upper Productive Series during the Pliocene. The latter contains the Fasila (Pereriv) and Balakhany units which are the principal oil and gas reservoirs (Abdullayev et al., 2012; Baganz et al., 2012; Green et al., 2009).

Palynological analyses of the Upper Productive Series in core samples from the offshore Azeri-Chirag-Gunashli (ACG) field showed that most of the mud-prone samples studied were of lacustrine origin (Reynolds and Lowe, 2004) and the associated reservoirs are interpreted as fluvial, fluvio-lacustrine and deltaic (Abdullayev et al., 2012; Bowman et al., 2008a, 2008b). Three principal 'palynofacies types' can be recognized: 'Delta Front', 'Caspian Lake' and 'Lake Margin' (Figure 11). 'Delta Front' associations are characterized by frequent Pinus and Pediastrum, and represent phases when catchment climate was relatively humid, and palaeo-Volga discharge relatively high (Figure 11a). The Pediastrum algae may be sourced from the catchment, ilmen and from the shallow, largely fresh waters at the delta front. 'Caspian Lake' associations (Figure 11b) contain increased pollen from mixed and swamp forest, locally common Amaranthaceae and consistent numbers of freshwater to brackish dinocysts, most often $S$. cruciformis and C. rugosum, and show some similarities with the kultuk in the modern delta. 'Lake Margin' associations (Figure 11c) are characterized by localized increases in fungal hyphae or spores, together with increased NAP and, in some instances, dinocysts. These 'Lake Margin' assemblages relate to periods of minimal runoff, with sub-aerial exposure of lake-margin muds and expansion of halophytic and xerophytic plant associations within the delta plain regions. The three palynofacies types described do not adequately account for all the palynological and depositional variations observed in the offshore area, and they are most directly applicable to the Fasila and lower Balakhany units. These 'palynofacies types' have sedimentary significance in that they broadly mirror the features and processes observed in the modern Volga delta, for example, by Belevich (1956, 1960, 1963), Rusakov (1990) and Kroonenberg et al. (1997; Figure 12). 'Delta Front' palynofacies in the Mio-Pliocene delta are associated with amalgamated to isolated channel sands, minor siltstone and mudstone which are the main hydrocarbon reservoirs in the Productive Series. They were deposited in shallow water, not more than tens of metres according to Reynolds and Lowe (2004), at the delta front (equivalent to the lower delta and avandelta in the present-day delta). 'Caspian Lake' palynofacies in the Mio-Pliocene delta are associated with finely laminated mudstones, siltstones and minor sandstone, which typically have low reservoir quality. They were deposited at the distal delta front to pro-delta (equivalent to the distal avandelta in the present-day delta); 'Lake Margin' palynofacies extended over very large areas of the basin during the latest Miocene and Pliocene in response to extremely low river runoff (Richards, unpublished). They vary in thickness by only a few millimetres to tens of metres, consisting mainly of fine-grained sediments with little or no reservoir quality. There is no exact analogue for the 'Lake Margin' palynofacies in the modern delta, although similar palynomorph assemblages (with frequent fungal bodies) occur in several of the Damchik cores associated with the early Holocene Mangyshlak and late Holocene Derbent lowstand events. True deltaic influences are diminished in the upper part of the Upper Productive Series in the Sabunchy and Surakhany units; outcrops are predominantly of fluvial origin (Vincent et al., 2010) with 'playa lake' sediments and thick evaporites present in the offshore area (Abdullayev et al., 2012). Potential analogues for these Upper Productive Series units include Lake Eyre, Australia, and some of the isolated lakes in central Asia, for example, the Karakiya depression, Kazakhstan (Richards, unpublished).

Both the Mio-Pliocene and modern deltas were deposited in closed lacustrine basins, not directly affected by marine influences, with sedimentation controlled by climate, fluvial discharge and base level, and both show evidence for significant variations in Caspian Sea level. The Holocene delta was largely aggradational during rising levels and progradational when levels were falling (Overeem et al., 2003), whereas the Mio-Pliocene delta was predominantly aggradational (Abdullayev et al., 2012) and shows more extremes of deposition as it represents the infilling of an underfilled lake (Bohacs, 2012; Green et al., 2009). Sediments deposited during the early Holocene Mangyshlak lowstand in the modern delta are characterized by largely reworked palynological assemblages, and similar reworking patterns can be seen in several intervals within Productive Series outcrops in Azerbaijan (Richards, unpublished). The modern delta supports largely cool temperate and semi-arid plant associations, whereas the MioPliocene delta shows good pollen evidence for the presence of warm temperate and swamp associations in some parts of the stratigraphic record (Richards, unpublished). In both cases, cooler climates are indicated by a southward expansion of the boreal forest belt, with higher frequencies of coniferous pollen (mainly Pinus) recorded. River margin trees during the Mio-Pliocene included frequent Taxodiaceae, which became extinct in the Caspian region towards the end of the early Pleistocene according to Filippova (1997), although the possibility of relict populations persisting more recently is considered by Sorrel et al. (2007). The 
(a)

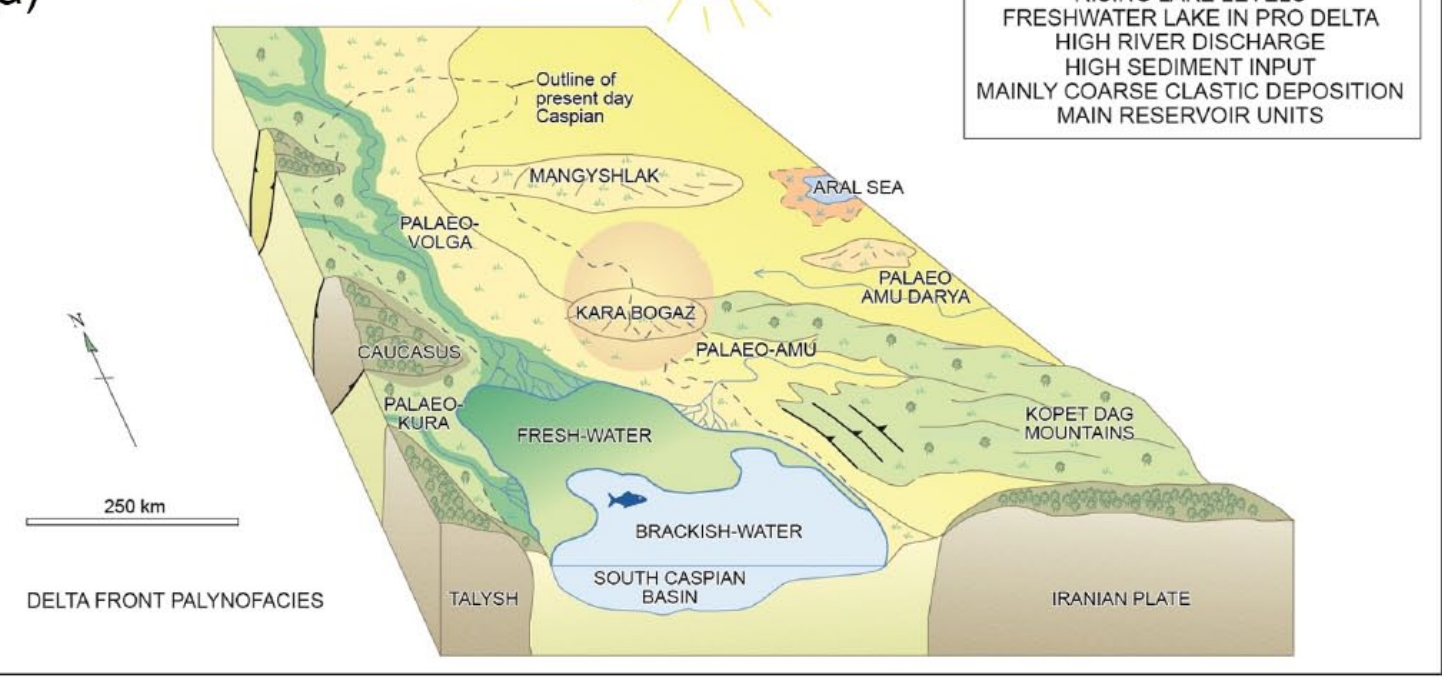

(b)

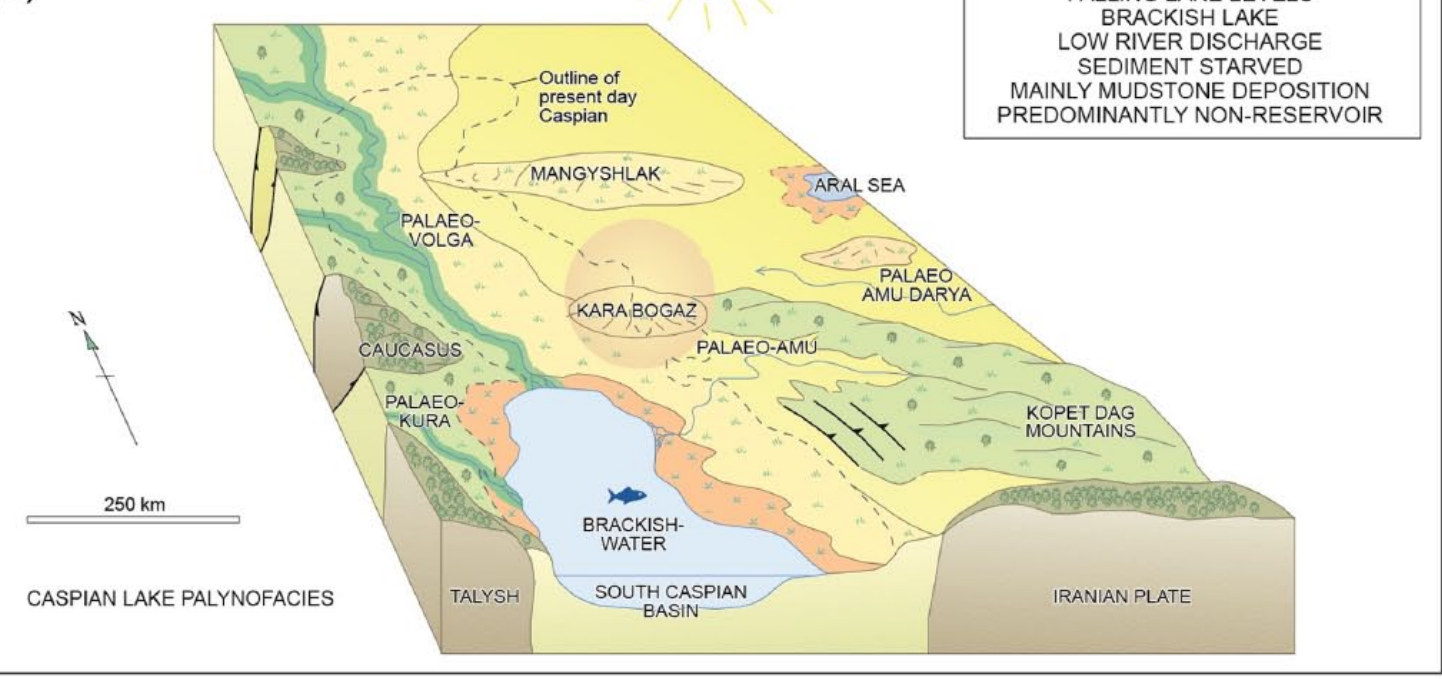

(c)

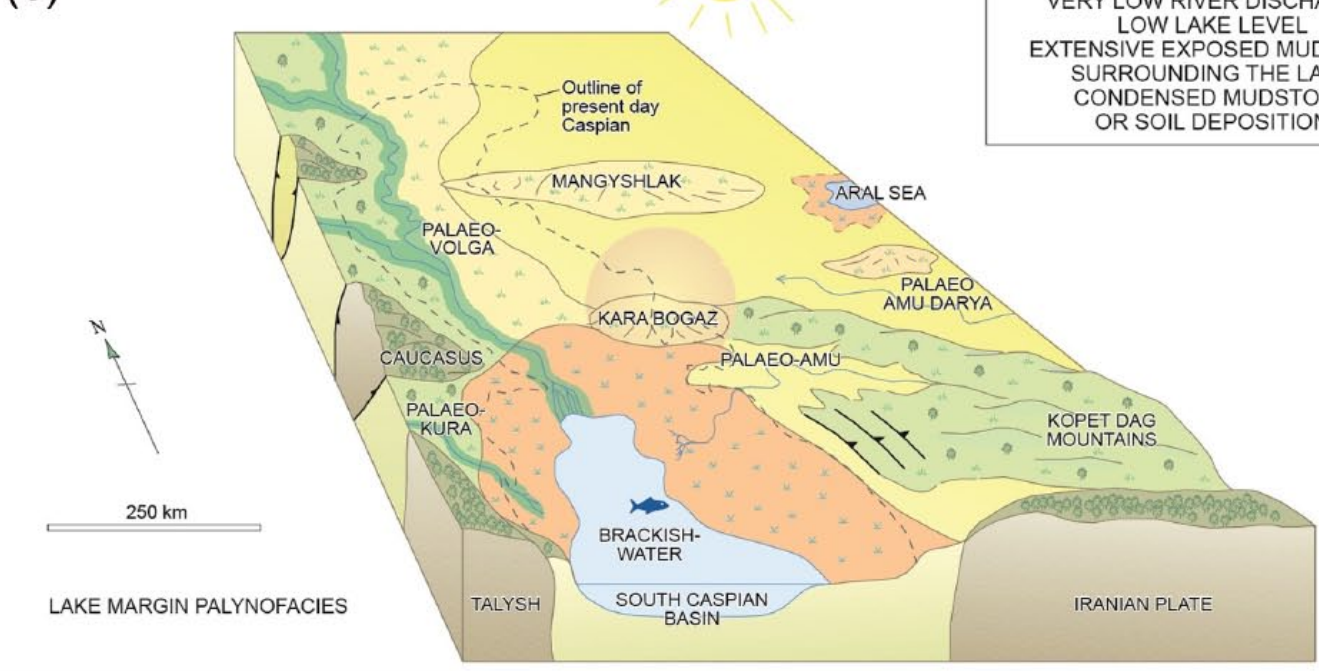

Desert/ Semi desert

Open steppe

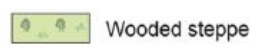

Salt marsh
Freshwater swamp

Mixed forest
ARID VOLGA CATCHMENT

FALLING LAKE LEVELS

BRACKISH LAKE LOW RIVER DISCHARGE

SEDIMENT STARVED

MAINLY MUDST REDOMINANTLY NON-RESERVOIR

RANIAN PLATE

Figure I I. Simplified depositional/palynofacies models for the Mio-Pliocene palaeo-Volga delta in the south Caspian basin. (a) 'Delta Front', (b) 'Caspian Lake' and (c) 'Lake Margin'. Reproduced with permission from BP Exploration (Caspian Sea) Ltd. 


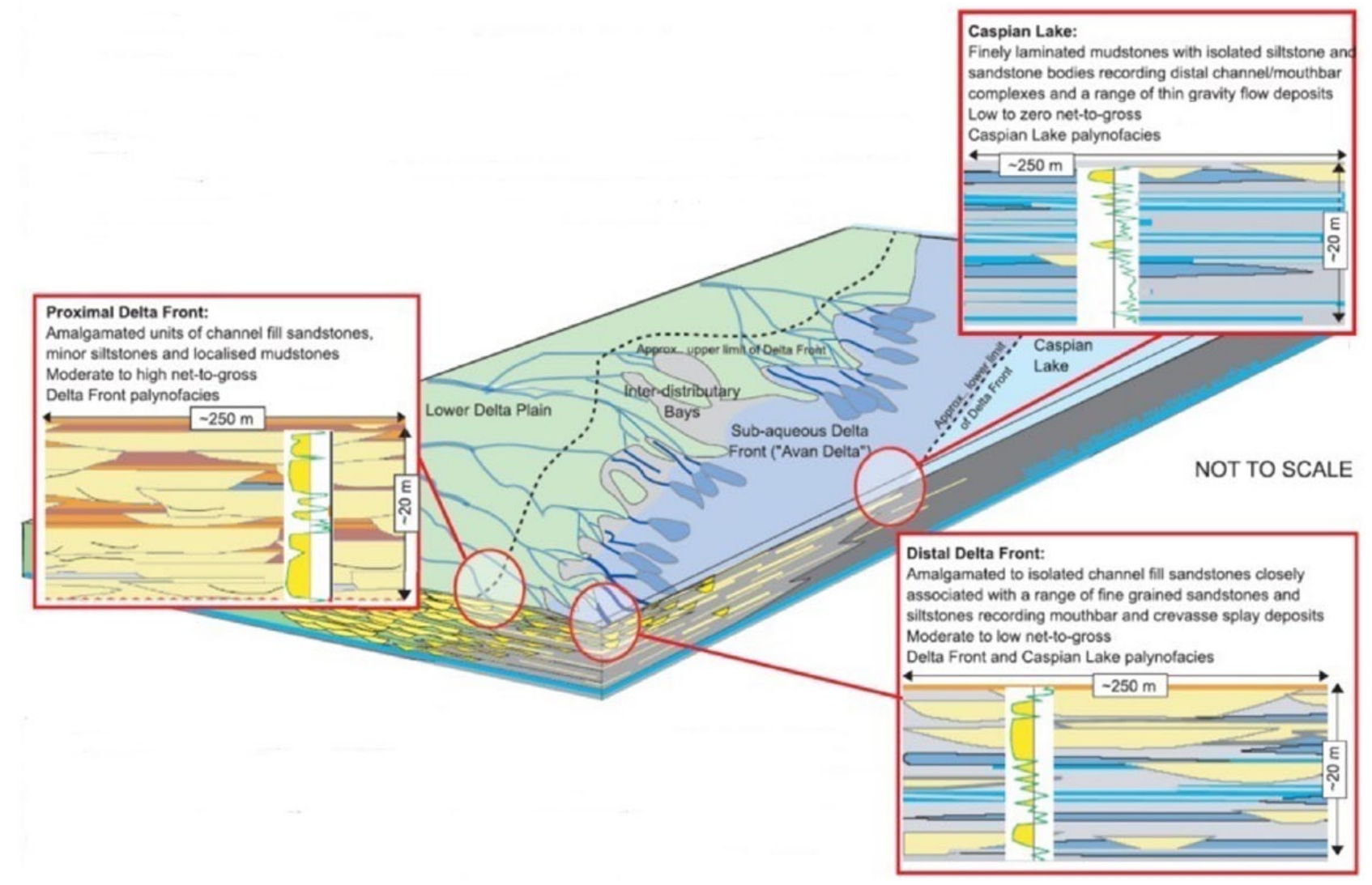

Figure 12. Schematic diagram of typical sediment distribution in the Mio-Pliocene palaeo-Volga delta at the ACG locality in the south Caspian basin showing analogies with sedimentary features in the modern delta and 'palynofacies types'. The inset panels are schematic cross-sections based on typical well sections within the Fasila and Balakhany units of the Upper Productive Series. High net-to-gross sediments have high sand content, low net-to-gross sediments have low sand content. Reproduced with permission from BP Exploration (Caspian Sea) Ltd.

niche occupied by Taxodiaceae in the Mio-Pliocene delta is filled by Salix in the modern delta. Steppe, desert and halophytic associations are probably represented by more or less the same pollen types (e.g. Poaceae, Asteraceae, Artemisia and Amaranthaceae) during both the Mio-Pliocene and Holocene, and are indicative of periods of dry climate. Dinocysts (e.g. S. cruciformis and C. rugosum) and algae (e.g. Pediastrum) occur in both the Mio-Pliocene and modern deltas, and are useful for estimating relative brackish and freshwater influences. Fungal bodies are also present in both deltas, and are thought to be broadly indicative of Caspian Sea relative lowstands.

\section{Conclusion}

New palynology and ostracod data from the Damchik region provide a record of Holocene vegetation and the sedimentary history of the lower Volga delta. Clusters of ${ }^{14} \mathrm{C}$ ages occur at 9010 $7720 \mathrm{cal}$. BP, $5640-3230 \mathrm{cal}$. BP and 1850-670 cal. BP and illustrate the main phases of active delta deposition. Further age refinement is obtained by correlation to a well-dated succession at Solenoe Zajmishche to the north. Average sedimentation rates at Damchik during the Holocene were in the region of $1.0-1.5 \mathrm{~mm}$ per annum.

There is a close similarity between the assemblages in the surface samples and the upper sections of the studied cores. AP and NAP are more or less equally represented in surface samples, with high proportions of Salix pollen derived from willow forest close to the sample collection locations, and other AP sourced from mixed forest within or close to the delta and from long-distance dispersal, for example, Pinus. NAP is sourced mainly from reedbeds within the lower delta (e.g. Poaceae) with other types (e.g. Amaranthaceae and Asteraceae) sourced from deltaic herb communities, nearby steppe and semi-desert. Aquatic pollen and ostracods in the surface samples indicate predominantly freshwater conditions with minor brackish influences in the lower delta and avandelta. Dinocysts present are low salinity to freshwater forms such as I. caspienense, S. cruciformis and P. cruciformis, the latter recorded for the first time in the Caspian Sea.

Deposition during the period 11,500-8900 cal. BP was linked with the Baer hills, the dune field formed in the north Caspian region during the Mangyshlak lowstand. Fungal spores are considered good indicators of aeolian activity, whereas reworked palynomorphs characterize infilled channel deposits. Freshwater to brackish deposition continued in the topographic lows between 8900 and $3770 \mathrm{cal}$. BP with periodic connections to the open water Caspian Sea. Widespread halophytic/xerophytic vegetation indicates a dry climate at least between 8120 and $7720 \mathrm{cal}$. BP. Vegetation in the delta region subsequently consisted of steppe and forest during periods of warmer and more humid climates, with boreal forest present in the Volga catchment. The period $3770-2080 \mathrm{cal}$. BP has evidence for forest or woodland close by during periods of climatic warming with frequent reworked palynomorphs indicating significant input from hinterland sources and active delta deposition at this time. Steppe vegetation was widespread and cold temperate forest present in the region from around $2080 \mathrm{cal}$. BP to present-day, indicated by increased proportions of NAP and localized peaks of Pinus and Betula. Episodes of rising Caspian Sea levels are marked by increased representation of aquatic plants such as Potamogeton and Sparganium when avandelta vegetation extended landwards. Fungal hyphae are probably linked with drier climates and soil formation during the Derbent regression at around the time of the 'Medieval Warm Period'. Further landward expansions of avandelta aquatic associations occurred within the last few hundred years due to rising Caspian Sea levels during the 'Little Ice Age'. 
Similarities and differences exist between the present-day Volga delta and the much larger oil and gas bearing Mio-Pliocene palaeo-Volga delta. Similar 'palynofacies types' occur in both the older and modern delta. However, the Holocene delta is only a partial analogue for the Mio-Pliocene Productive Series, as it is a much smaller feature representing only the last 12,000 years or so of deposition. The Pleistocene 'wandering delta' described by Kroonenberg et al. (1997) is a more complete analogue. This is a much larger and more varied deltaic succession, deposited over a large area to the north of the present-day Caspian Sea during the last $700 \mathrm{kyr}$ or more years, and contains a sedimentary record, not yet fully studied, of large-and small-scale events caused by rapid changes in Caspian Sea level.

\section{Acknowledgements}

Thanks are due to those who made the data acquisition in the modern Volga delta possible by allowing access and sample collection. In particular, the authors would like to thank Alexander Gorbunov (Astrakhan Biosphere Reserve), Oleg Levchenko (P.P. Shirshov Institute of Oceanology), Marc Debatist and Tine Missiaen (University of Ghent), and Nicolai Kasimov, Michael Lychagin, Alexander Svitoch and Tamara Yanina (Moscow State University) for assistance with various aspects of this study. BP Exploration (Caspian Sea) Ltd. gave permission to publish the schematic diagrams (Figures 11 and 12). Tony Reynolds and Steve Lowe have contributed valuable discussion over many years and are the original authors of Figure 11. Andrew Bowman arranged a field visit to the Volga region in 2008, and provided Figure 12. Greg Riley, Nazim Abdullayev, Simon Grant and others at BP Exploration (Caspian Sea) Ltd. have facilitated the ongoing Caspian research, as have Steve Vincent and Clare Davies of CASP, United Kingdom. Alison Davies of the Mapping Company Ltd. carried out the original art work on several of the figures, and Irina Overeem provided her original vegetation diagrams. Klaus Arpe provided the precipitation diagram (Figure 1b). Palynological preparations in the United Kingdom were made by Malcolm Jones (PLS Ltd.) and Jonah Chitolie (GeoTechniques Research), and assistance with pollen counts provided by Fiona Richards. Original radiocarbon ages were provided by Klaas van der Borg (Utrecht) and new calibrations for this paper were made by Ron Hatfield of Beta Analytic Inc. Valuable comments on the original manuscript were given by Henry Hooghiemstra and Carina Hoorn, University of Amsterdam. The final manuscript was improved significantly by reviewers Fabienne Marret and André Rochon.

\section{Funding}

Funding for the data collection and field work was provided from the following sources: 1 - IGCP-UNESCO 2003-2008 (Project 481 CASPAGE, Dating Caspian Sea Level Change); 2 - NWO, Netherlands Science Foundation and RFFI, Russian Science Foundation 2005-2008 (Programme: 'VHR Seismic Stratigraphy and Paleoecology of the Holocene Volga Delta'); and 3 - BP Exploration (Caspian Sea) Sea Ltd. (Azeri-Chirag-Gunashli) 2005-2008 ('Unravelling the Small-Scale Stratigraphy and Sediment Dynamics of the Modern Volga Delta Using VHR Marine Geophysics'). The palynological work was funded jointly by BP Exploration (Caspian Sea) Ltd., Delft University of Technology and KrA Stratigraphic Ltd. Ostracod analyses were funded by StrataData Ltd. and funding for two additional radiocarbon dates provided by Deltares. Provision for open access publication was made available by the Institute for the Environment, Brunel University.

\section{Note}

1. The Amaranthaceae family now includes most plants, and therefore pollen, previously assigned within the Chenopodiaceae (see Kadereit et al., 2003; Müller and Borsch, 2005).

\section{References}

Abdullayev NR, Riley GW and Bowman AP (2012) Regional controls on lacustrine sandstone reservoirs: The Pliocene of the South Caspian basin. In: Baganz OW, Bartov Y, Bohacs $\mathrm{K}$ et al. (eds) Lacustrine Sandstone Reservoirs and Hydrocarbon Systems (AAPG Memoir 95). Tulsa, OK: The American Association of Petroleum Geologists, pp. 71-98.

Abreu V and Nummedal D (2007) Miocene to Quaternary sequence stratigraphy in the South and Central Caspian basins. In: Yilmaz PO and Isaksen GH (eds) Oil and Gas of the Greater Caspian Area (AAPG Studies in Geology 55). Tulsa, OK: The American Association of Petroleum Geologists, pp. 65-86.

Agalarova DA, Kadyrova ZK and Kulieva SA (1961) Ostracoda of the Pliocene and Post-Pliocene Deposits of Azerbaijan. Baku: Azerbaijan State Publisher, 420 pp. (in Russian).

Alekseevskiy NI, Aibulatov DN and Povalishnikova ES (2010) Evolution of the Volga delta for the last 200 years. In: The Caspian Region: Environmental Consequences of the Climate Change; Proceedings of the International Conference, Moscow, 14-16 October, pp. 38-41. Moscow: Faculty of Geography, Moscow State University. Available at: http://media.geogr.msu.ru/Caspian_2010/caspian_conference_2010.pdf.

Allen MB $\bar{B}$, Jones S, Ismail-Zadeh A et al. (2002) Onset of subduction as a cause of rapid Pliocene-Quaternary subsidence in the South Caspian basin. Geology 30(9): 775-778.

Allen MB, Vincent SJ, Alsop GI et al. (2003) Late Cenozoic deformation in the South Caspian region: Effects of a rigid basement block within a collision zone. Tectonophysics 366(3-4): 223-239.

Arpe K, Leroy SAG, Lahijani $\mathrm{H}$ et al. (2012) Impact of the European Russia drought in 2010 on the Caspian Sea level. Hydrology and Earth System Sciences 16(1): 19-27.

Badertscher S, Fleitmann D, Cheng H et al. (2011) Pleistocene water intrusions from the Mediterranean and Caspian seas into the Black Sea. Nature Geoscience 4(4): 236-239.

Badukova EN and Kalashnikov AY (2010) Development of the Turali region (Dagestan Coast) in Late Holocene according to geological, geomorphological and geophysical data. In: The Caspian Region: Environmental Consequences of the Climate Change; Proceedings of the International Conference, Moscow, 14-16 October, pp. 69-73. Moscow: Faculty of Geography, Moscow State University. Available at: http://media. geogr.msu.ru/Caspian_2010/caspian_conference_2010.pdf.

Baganz OW, Barirov E, Michael GE et al. (2012) Productive Series play of the paleo-Volga delta, south Caspian basin: Exploration history, sedimentation and petroleum system. In: Baganz OW, Bartov Y, Bohacs K et al. (eds) Lacustrine Sandstone Reservoirs and Hydrocarbon Systems (AAPG Memoir 95). Tulsa, OK: The American Association of Petroleum Geologists, pp. 57-70.

Baldina EA and Labutina IA (2010) Research and mapping at Volga delta region based on remote sensing and GIS methods. In: The Caspian Region: Environmental Consequences of the Climate Change; Proceedings of the International Conference, Moscow, 14-16 October, pp. 180-184. Moscow: Faculty of Geography, Moscow State University. Available at: http://media.geogr.msu.ru/Caspian_2010/caspian_conference_2010.pdf.

Baldina EA, De Leeuw J, Gorbunov AK et al. (1999) Vegetation change in the Astrakhanskiy Biosphere Reserve (lower Volga delta, Russia) in relation to Caspian Sea level fluctuation. Environmental Conservation 26(3): 169-178.

Baltes N (1971) Pliocene Dinoflagellata and Acritarcha in Romania. In: Farinacci A (ed.) Proceedings of the Second Planktonic Conference. Rome: Edizioni Technoscienza, pp. 1-16. 
Belevich EF (1956) About the history of the Volga delta. Reports of the Oceanographic Committee of Academy of Science USSR 1: 37-56 (in Russian).

Belevich EF (1960) About the vertical growth of islands in the lower area of the Volga delta. Reports of the Oceanographic Committee of Academy of Science USSR 6: 55-56 (in Russian).

Belevich EF (1963) Subdivision of the Volga delta. Reports of the Astrakhan Nature Reserve 7: 401-421 (in Russian).

Bobrov AE, Kuprianova LA, Litvintseva MV et al. (1983) Spores and Pollen of Gymnosperms from the Flora of the European Part of the USSR. Leningrad: Nauka, 208 pp. (in Russian).

Bohacs KM (2012) Relation of hydrocarbon reservoir potential to lake-basin type: An integral approach to unravelling complex genetic relations among fluvial, lake plain, lake margin and lake center strata. In: Baganz OW, Bartov Y, Bohacs K et al. (eds) Lacustrine Sandstone Reservoirs and Hydrocarbon Systems (AAPG Memoir 95). Tulsa, OK: The American Association of Petroleum Geologists, pp. 13-56.

Bolikhovskaya NS (1990) Palynological indication of environment changes in the Lower Volga region during the last 10,000 years. In: Lebedev LI and Maev EG (eds) Issues of Geology and Geomorphology of Caspian Sea. Moscow: Nauka, pp. 52-68 (in Russian).

Bolikhovskaya NS and Kasimov NS (2008) Landscape and climate variability of the Lower Volga River Region during the last 10 kyr. In: Bolikhovskaya NS and Kaplin PA (eds) Problems of Paleogeography and Stratigraphy of the Pleistocene, vol. 2. Moscow: Geography Faculty Press, pp. 99-117 (in Russian).

Bolikhovskaya NS and Kasimov NS (2010) The evolution of climate and landscapes of the lower Volga region during the Holocene. Geography, Environment, Sustainability 2(3): 7897. Available at: http://www.geogr.msu.ru/GESJournal/.

Bowman AP, Kuramshina N, Slack J et al. (2008a) Beyond the Pereriv; integrated reservoir characterization of the Balakhany reservoirs in the ACG Field, South Caspian Basin, Azerbaijan. Extended abstract. In: EAGE International Conference on the Geology and Hydrocarbon Potential of the Caspian and Black Sea, Baku, 6-8 October.

Bowman AP, Martines M, Reynolds AD et al. (2008b) Lacustrine delta reservoirs of the giant ACG Field, South Caspian Basin, offshore Azerbaijan. Abstract. In: Geological Society of London Research Conference: Rivers, Estuaries, Deltas and Beaches, London, 6-7 November.

Cambon G, Suc J-P, Aloisi J-C et al. (1997) Modern pollen deposition in the Rhône delta area (lagoonal and marine sediments), France. Grana 36: 105-113.

Chepalyga AL (2007) The Late Glacial great flood in the PontoCaspian basin. In: Yanko-Hombach V, Gilbert AS, Panin $\mathrm{N}$ et al. (eds) The Black Sea Flood Question. Dordrecht: Springer, pp. 119-148.

Corradini D and Biffi U (1988) Étude des dinokystes à la limite Messinian-Pliocène dans la coupe Cava Serredi, Toscane, Italie. Bulletin des Centres de Recherches Exploration-Production Elf-Aquitaine 12(1): 221-236.

Dumont HJ (1998) The Caspian Lake: History, biota, structure and function. Limnology and Oceanography 43(1): 44-52.

Erdtman G (1971) Pollen Morphology and Plant Taxonomy: Angiosperms (an introduction to palynology I). New York: Hafner, 533 pp.

Ferronsky VI, Polyakov VA, Kuprin PN et al. (1999) The nature of variations in the level of the Caspian Sea (based on bottom sediment data). Water Resources 26: 583-596.

Filipova-Marinova M, Pavlov D, Coolen M et al. (2013) First high-resolution marinopalynological stratigraphy of Late Quaternary sediments from the central part of the Bulgarian Black Sea area. Quaternary International 293: 170-183.
Filippova NY (1997) Palynology of the Upper Pliocene to Middle Pleistocene Deposits in the Southern Part of the Caspian Region (transactions volume 502). Moscow: GEOS, $162 \mathrm{pp}$. (in Russian with English summary).

Forte AM and Cowgill E (2013) Late Cenozoic base-level variations of the Caspian Sea: A review of its history and proposed driving mechanisms. Palaeogeography, Palaeoclimatology, Palaeoecology 386: 392-407.

Green T, Abdullayev N, Hossack J et al. (2009) Sedimentation and subsidence in the south Caspian basin, Azerbaijan. In: Brunet M-F, Wilmsen M and Granath JW (eds) South Caspian to Central Iran Basins. London: Geological Society of London (special publication no. 312), pp. 241-260.

Grimm EC (1987) CONISS: A FORTRAN 77 program for stratigraphically constrained cluster analysis by the method of incremental sum of squares. Computers and Geosciences 13(1): 13-35.

Hinds D, Aliyeva E, Allen MB et al. (2004) Sedimentation in a discharge dominated fluvial lacustrine system: The Neogene Productive Series of the South Caspian Basin. Marine and Petroleum Geology 21(5): 613-638.

Hoogendoorn RM, Boels JF, Kroonenberg SB et al. (2005) Development of the Kura delta, Azerbaijan; A record of Holocene Caspian Sea-level changes. Marine Geology 222223: 359-380.

Hoogendoorn RM, Levchenko O, Missiaen T et al. (2010) High resolution seismic stratigraphy of the modern Volga delta, Russia. In: The Caspian Region: Environmental Consequences of the Climate Change; Proceedings of the International Conference, Moscow, 14-16 October, pp. 32-37. Moscow: Faculty of Geography, Moscow State University. Available at: http://media.geogr.msu.ru/Caspian_2010/caspian_conference_2010.pdf.

Ivkina $\bar{N}$ (2010) Dangerous wind affected phenomena in the Kazakhstan part of the Caspian Sea and the method of their forecasting. In: The Caspian Region: Environmental Consequences of the Climate Change; Proceedings of the International Conference, Moscow, 14-16 October, pp. 326-329. Moscow: Faculty of Geography, Moscow State University. Available at: http://media.geogr.msu.ru/Caspian_2010/caspian_conference_2010.pdf.

Kadereit G, Borsch T, Weising K et al. (2003) Phylogeny of Amaranthaceae and Chenopodiaceae and the evolution of $\mathrm{C} 4$ photosynthesis. International Journal of Plant Sciences 164(6): 959-986.

Kaplin P (1995) The Caspian Sea: Its past present and future. In: Mandych AF (ed.) Enclosed Seas and Large Lakes of Eastern Europe and Middle Asia. Amsterdam: SPB Academic Publishing, pp. 71-117.

Knystautas A (1987) The Natural History of the USSR. London: Century Hutchinson, 224 pp.

Kosarev AN (2005) Physico-geographical conditions of the Caspian Sea. In: Kostianoy AG and Kosarev AN (eds) The Caspian Sea Environment. Berlin/Heidelberg: SpringerVerlag, pp. 5-31.

Kosarev AN and Yablonskaya EA (1994) The Caspian Sea. The Hague: SPB Academic Publishing, 259 pp.

Kouli K, Brinkhuis H and Dale B (2001) Spiniferites cruciformis: A freshwater dinoflagellate cyst. Review of Palaeobotany and Palynology 113(4): 273-286.

Kroonenberg SB, Kasimov NS and Lychagin MY (2008) The Caspian Sea, a natural laboratory for sea-level change. Geography Environment Sustainability 1: 22-37.

Kroonenberg SB, Rusakov GV and Svitoch AA (1997) The wandering of the Volga delta: A response to rapid Caspian Sea-level change. Sedimentary Geology 107(3-4): 189-209. 
Kroonenberg SB, Abdurakhmanov GM, Badyukova EN et al. (2007) Solar-forced 2600 BP and 'Little Ice Age' highstands of the Caspian Sea. Quaternary International 173-174: 137-143.

Kroonenberg SB, Simmons MD, Alekseevski N et al. (2005) Two deltas, two basins, one river, one sea: The modern Volga delta as an analogue of the Neogene Productive Series, South Caspian Basin. In: Giosan L and Bhattacharya J (eds) River Deltas-Concepts, Models and Examples. Tulsa, OK: SEPM (Society for Sedimentary Geology, special publication no. 83), pp. 231-256.

Kuprianova LA and Alyoshina LA (1972) Pollen and Spores of Plants from the Flora of the European Part of the USSR. Leningrad: Nauka, 170 pp. (in Russian).

Kuprianova LA and Alyoshina LA (1978) Pollen of Dicotyledonous Plants from the Flora of the European Part of the USSR. Leningrad: Nauka, 184 pp. (in Russian).

Labutina IA, Zhivogliad AF, Gorbunov AK et al. (1995) The Astrakhanskiy Biosphere Reserve GIS. Part 3: Vegetation map. ITC Journal 3: 197-201.

Leroy SAG (2010) Palaeoenvironmental and palaeoclimatic changes in the Caspian Sea region since the Lateglacial from palynological analyses of marine sediment cores. Geography, Environment, Sustainability 2(3): 32-41. Available at: http:// www.geogr.msu.ru/GESJournal/.

Leroy SAG and Albay M (2010) Palynomorphs of brackish and marine species in cores from the freshwater Lake Sapanca, NW Turkey: Further evidence of palaeo-contacts with the Black Sea? Review of Palaeobotany and Palynology 160(34): 181-188.

Leroy SAG, Boyraz S and Gürbüz A (2009) High-resolution palynological analysis in Lake Sapanca as a tool to detect earthquakes on the North Anatolian Fault. Quaternary Science Reviews 28: 2616-2632.

Leroy SAG, Kakroodi AA, Kroonenberg SB et al. (2013a) Holocene vegetation history and sea level changes in the SE corner of the Caspian Sea: Relevance to SW Asia climate. Quaternary Science Reviews 70: 28-47.

Leroy SAG, Lahijani HAK, Djamali M et al. (2011) Late 'Little Ice Age' palaeoenvironmental records from the Anzali and Amirkola Lagoons (south Caspian Sea): Vegetation and sea level changes. Palaeogeography, Palaeoclimatology, Palaeoecology 302(3-4): 415-434

Leroy SAG, Lahijani HAK, Reyss J-L et al. (2013b) A two-step expansion of the dinocyst Lingulodinium machaerophorum in the Caspian Sea: The role of changing environment. Quaternary Science Reviews 77: 31-45.

Leroy SAG, Marret F, Gibert E et al. (2007) River inflow and salinity changes in the Caspian Sea during the last 5500 years. Quaternary Science Reviews 26: 3359-3383.

Leroy SAG, Tudryn A, Chalié F et al. (2013c) From the Allerød to the mid-Holocene: Palynological evidence from the south basin of the Caspian Sea. Quaternary Science Reviews 78: 77-97.

Lewis J and Hallett R (1997) Lingulodinium polyedrum (Gonyaulax polyedra) a blooming dinoflagellate. In: Ansell AD, Gibson RN and Barnes M (eds) Oceanography and Marine Biology: An Annual Review. London: UCL Press, pp. 97-161.

Losev GA, Jans L, Pilipenko VN et al. (1998) Flora of the Volga delta: A check list of the vascular plants of the Volga delta, Russia. Report no 98.026. Lelystad: RIZA (Dutch Institute for Inland Water Management), $128 \mathrm{pp}$.

Lychagin MY, Baldina EA, Gorbunov AK et al. (1995) The Astrakhanskiy Biosphere Reserve GIS. Part 1: Present status and perspectives. ITC Journal 3: 189-192.

Magny M, Begeot C, Guiot J et al. (2003) Contrasting patterns of hydrological changes in Europe in response to Holocene climate cooling phases. Quaternary Science Reviews 22: 1589-1596.

Marret F, Leroy SAG, Chalié F et al. (2004) New organic-walled dinoflagellate cysts from recent sediments of the central Asian seas. Review of Palaeobotany and Palynology 129(12): $1-20$.

Mayev EG (1994) Regressions of the Caspian Sea. Geomorphology 2: 94-101 (in Russian).

Mayev EG (2010) Mangyshlak regression of the Caspian Sea: Relationship with climate. In: The Caspian Region: Environmental Consequences of the Climate Change; Proceedings of the International Conference, Moscow, 14-16 October, pp. 107-109. Moscow: Faculty of Geography, Moscow State University. Available at: http://media.geogr.msu.ru/Caspian_2010/caspian_conference_2010.pdf.

Meisch C (2000) Freshwater Ostracoda of Western and Central Europe. Heidelberg, Berlin: Spektrum Akademischer Verlag, $522 \mathrm{pp}$.

Mertens KN, Bradley LR, Takano Y et al. (2012) Quantitative estimation of Holocene surface salinity variation in the Black Sea using dinoflagellate cyst process length. Quaternary Science Reviews 39: 45-59.

Mertens KN, Ribeiro S, Bouimetarhan I et al. (2009) Process length variation in cysts of a dinoflagellate, Lingulodinium machaerophorum, in surface sediments investigating its potential as salinity proxy. Marine Micropaleontology 70(12): $54-69$.

Moore PD and Webb JA (1978) An Illustrated Guide to Pollen Analysis. London: Hodder \& Stoughton, 133 pp.

Mudie PJ, Aksu AE and Yasar D (2001) Late Quaternary dinoflagellate cysts from the Black, Marmara and Aegean seas: Variations in assemblages, morphology and paleosalinity. Marine Micropaleontology 43(1-2): 155-178.

Mudie PJ, Leroy SAG, Marret F et al. (2011) Nonpollen palynomorphs: Indicators of salinity and environmental change in the Caspian-Black Sea-Mediterranean corridor. In: Buynevich I, Yanko-Hombach V, Gilbert AS et al. (eds) Geology and Geoarchaeology of the Black Sea Region: Beyond the Flood Hypothesis. Boulder, CO: Geological Society of America (special publication no. 473), pp. 89-115.

Müller K and Borsch T (2005) Phylogenetics of Amaranthaceae based on matK/trnK sequence data: Evidence from parsimony, likelihood, and Bayesian analyses. Annals of the Missouri Botanical Garden 92(1): 66-102.

Naderi Beni A, Lahijani HAK, Mousavi Harami R et al. (2013a) Caspian Sea level changes during the last millennium: Historical and geological evidences from the south Caspian Sea. Climate of the Past 9(4): 1645-1665.

Naderi Beni A, Lahijani HAK, Mousavi Harami R et al. (2013b) Development of spit-lagoon complexes in response to 'Little Ice Age' rapid sea-level changes in the central Guilan coast, South Caspian Sea, Iran. Geomorphology 187: 11-26.

Nikolayev VA (2007) Eurasian semi-desert: 100th anniversary of the discovery of the natural semi-desert zone. Geography (Moscow University Herald Series 5) 6: 3-9 (in Russian).

Ogorodov SA and Arkhipov VV (2010) Caspian Sea bottom scouring by hummocky ice floes. In: The Caspian Region: Environmental Consequences of the Climate Change; Proceedings of the International Conference, Moscow, 14-16 October, pp. 286-290. Moscow: Faculty of Geography, Moscow State University. Available at: http://media.geogr.msu.ru/ Caspian_2010/caspian_conference_2010.pdf.

Overeem I, Kroonenberg SB, Veldkamp A et al. (2003) Smallscale stratigraphy in a large ramp delta: Recent and Holocene sedimentation in the Volga delta, Caspian Sea. Sedimentary Geology 159(3-4): 133-157. 
Popescu S-M, Dalesme F, Jouannic G et al. (2009) Galeacysta etrusca complex: Dinoflagellate cyst marker of Paratethyan influxes to the Mediterranean Sea before and after the peak of the Messinian salinity crisis. Palynology 33: 105-134.

Ramsar Sites Information Service (2014) http://www.ramsar.wetlands.org (accessed 23 January 2014).

Reimer PJ, Baillie MGL, Bard E et al. (2009) INTCAL09 and MARINE09 radiocarbon age calibration curves, 0-50,000 years cal BP. Radiocarbon 51(4): 1111-1150.

Reynolds AD and Lowe S (2004) Continuous core from the Pliocene Productive Series: Evidence for a fluvially dominated delta. In: Abstract for Core Workshop: AAPG/ASPG International Hedberg Research Conference, Baku, 17-21 May.

Reynolds AD, Simmons MD, Bowman MBJ et al. (1998) Implications of outcrop geology for reservoirs in the Neogene Productive Series: Apsheron Peninsula, Azerbaijan. The American Association of Petroleum Geologists Bulletin 82(1): 25-49.

Richards K and Bolikhovskaya NS (2010) Palynology of pre-Holocene and Holocene shallow cores from the Damchik region of the Volga delta: Palynological assemblages, zones, depositional environments and Caspian Sea level. In: The Caspian Region: Environmental Consequences of the Climate Change: Proceedings of the International Conference, Moscow, 14-16 October, pp. 126-129. Moscow: Faculty of Geography, Moscow State University. Available at: http://media.geogr.msu.ru/ Caspian_2010/caspian_conference_2010.pdf.

Rochon A, Mudie PJ, Aksu AE et al. (2002) Pterocysta cruciformis gen. nov.: A new dinoflagellate cyst from Pleistocene glacial stage sediments of the Black and Marmara seas. Palynology 26: 95-105.

Rusakov GV (1990) Geomorphological subdivision of the Volga delta. Geomorphology 3: 99-106 (in Russian).

Rychagov GI (1977) The Pleistocene History of the Caspian Sea. Moscow: Moscow University Press, 267 pp. (in Russian).

Rychagov GI (1997) Holocene oscillations of the Caspian Sea and forecasts based on palaeogeographical reconstructions. Quaternary International 41-42: 167-172.

Rychagov GI, Korotaev VN and Chernov AV (2010) History of formation palaeodeltas of lower Volga deltas. Geography, Environment, Sustainability 1(3): 4-15. Available at: http:// www.geogr.msu.ru/GESJournal/.

Sal'nikov AL, Pilipenko VN and Sal'nikova NA (2010) Hydrological regimen features of delta Volga. In: The Caspian Region: Environmental Consequences of the Climate Change; Proceedings of the International Conference, Moscow, 14-16 October, pp. 212-216. Moscow: Faculty of Geography, Moscow State University. Available at: http://media.geogr.msu.ru/ Caspian_2010/caspian_conference_2010.pdf.

Sidorchuk AY, Panin AV and Borisova O (2009) Morphology of river channels and surface runoff in the Volga River basin (East European Plain) during the Late Glacial period. Geomorphology 113(3-4): 137-157.

Sorrel P, Popescu S-M, Head MJ et al. (2006) Hydrographic development of the Aral Sea during the last 2000 years based on a quantitative analysis of dinoflagellate cysts. Palaeogeography, Palaeoclimatology, Palaeoecology 234(2-4): 304-327.

Sorrel P, Popescu S-M, Klotz S et al. (2007) Climate variability in the Aral Sea basin (Central Asia) during the late Holocene based on vegetation changes. Quaternary Research 67(3): $357-370$

Spidchenko AN (1973) Caspian tides. Meteorologia e Hidrologia 5: 98-100 (in Russian).

Svitoch AA (2009) Khvalynian transgression of the Caspian Sea was not a result of water overflow from the Siberian proglacial lakes, nor a prototype of the Noachian flood. Quaternary International 197: 115-125.

Svitoch AA (2010) The Neoeuxinian basin of the Black Sea and the Khvalynian transgression of the Caspian Sea. Quaternary International 225: 230-234.

Thomas ER, Wolff EW, Mulvaney R et al. (2007) The $8.2 \mathrm{kyr}$ event from Greenland ice cores. Quaternary Science Reviews 26: $70-81$.

Traverse A (1978) Palynological analysis of DSDP Leg 42B (1975) cores from the Black Sea. In: Ross DA and Yeprochnov YP (eds) Initial Reports of the Deep Sea Drilling Project, vol. 42. Washington, DC: Government Printing Office, pp. 993-1015.

Tudryn A, Chalié F, Lavrushin Yu A et al. (2012) Late Quaternary Caspian Sea environment: Late Khazarian and Early Khvalynian transgressions from the lower reaches of the Volga river. Quaternary International 292: 193-204.

Van Baak CGC, Vasiliev I, Stoica M et al. (2013) A magnetostratigraphic time frame for Plio-Pleistocene transgressions in the South Caspian Basin, Azerbaijan. Global and Planetary Change 103: 119-134.

van Geel B (2001) Non-pollen palynomorphs. In: Smol JP, Birks HJB and Last WM (eds) Tracking Environmental Change Using Lake Sediments. Volume 3: Terrestrial, Algal and Silicaceous Indicators. Dordrecht: Kluwer Academic, pp. 99-119.

van Geel B and Renssen H (1998) Abrupt climate change around 2650 BP in NW Europe. In: Issar A and Brown N (eds) Water, Environment and Society in Times of Climate Change. Dordrecht: Kluwer Academic, pp. 21-41.

Varushchenko SI, Varushchenko AN and Klige RK (1987) Change of Regime of Caspian Sea and Drainless Water Bodies in Paleotime. Moscow: Nauka, 239 pp. (in Russian).

Vincent SJ, Davies CE, Richards K et al. (2010) Contrasting Pliocene fluvial depositional systems within the rapidly subsiding South Caspian Basin; A case study of the palaeo-Volga and palaeo-Kura river systems in the Surakhany Suite, Upper Productive Series, onshore Azerbaijan. Marine and Petroleum Geology 27(10): 2079-2106.

Vronsky VA (1976) Marine Palynology of the Southern Seas. Rostov-on-Don: Publishing House of Rostov University, 200 pp. (in Russian).

Wall D and Dale B (1973) Paleosalinity relationships of dinoflagellates in late Quaternary of the Black Sea. Geoscience and Man 7: 95-102.

Wall D, Dale B and Harada K (1973) Descriptions of new fossil dinoflagellates from the Late Quaternary of the Black Sea. Micropalaeontology 19(1): 18-31.

Yanina TA (2012) Correlation of the Late Pleistocene paleogeographical events of the Caspian Sea and Russian Plain. Quaternary International 271: 120-129.

Zonneveld KAF, Marret F, Versteegh GJM et al. (2013) Atlas of modern dinoflagellate cyst distribution based on 2405 data points. Review of Palaeobotany and Palynology 191: 1-197. 